Review

\title{
Metallic Scaffolds for Bone Regeneration
}

\section{Kelly Alvarez ${ }^{1}$ and Hideo Nakajima ${ }^{2, *}$}

1 Center for Geo-Environmental Science, Faculty of Engineering and Resource Science, Akita University, 1-1 Tegata Gakuen-machi, Akita 010-8502, Japan; E-Mail: kelly@gipc.akita-u.ac.jp

2 The Institute of Scientific and Industrial Research, Osaka University, Ibaraki, Osaka 567-0047, Japan

* Author to whom correspondence should be addressed; E-Mail: nakajima@sanken.osaka-u.ac.jp; Tel. +81-6-6879-8435; Fax: +81-6-6879-8439

Received: 19 June 2009; in revised form: 20 July 2009 / Accepted: 21 July 2009 /

Published: 23 July 2009

\begin{abstract}
Bone tissue engineering is an emerging interdisciplinary field in Science, combining expertise in medicine, material science and biomechanics. Hard tissue engineering research is focused mainly in two areas, osteo and dental clinical applications. There is a lot of exciting research being performed worldwide in developing novel scaffolds for tissue engineering. Although, nowadays the majority of the research effort is in the development of scaffolds for non-load bearing applications, primarily using soft natural or synthetic polymers or natural scaffolds for soft tissue engineering; metallic scaffolds aimed for hard tissue engineering have been also the subject of in vitro and in vivo research and industrial development. In this article, descriptions of the different manufacturing technologies available to fabricate metallic scaffolds and a compilation of the reported biocompatibility of the currently developed metallic scaffolds have been performed. Finally, we highlight the positive aspects and the remaining problems that will drive future research in metallic constructs aimed for the reconstruction and repair of bone.
\end{abstract}

Keywords: metallic bone scaffolds; biocompatible metals; load-bearing porous structures; 3-D metallic constructs; bone tissue engineering 


\section{Introduction}

Human skeletal tissues have complex three-dimensional (3-D) geometries and highly organized internal architectures, which cannot be simply emulated by cells maintained in two-dimensions. Bone is a complex porous composite structure with specific characteristics such as viscoelasticity and anisotropy, both in morphology and mechanical properties [1]. The unique mechanical performance of natural bone is characterized by high toughness, high specific strength, and low stiffness. Porous scaffolds are central to hard tissue engineering strategies because they provide a 3-D framework for delivering reparative cells or regenerative factors in an organized manner to repair or regenerate damaged tissues. Since hard tissues are responsible for the body mechanical stability, materials aimed for repairing, substitution and/or restoration of hard tissues must possess strength, resistance to corrosion/degradation, have a good biocompatibility and exhibit good wear resistance.

The development of successful scaffolds for bone tissue engineering requires a concurrent engineering approach that combines different research fields. During the last three decades, researchers have tailored metallic scaffolds that are useful for a wide variety of medical and dental applications. Surface modification of already proved biocompatible metals is an essential requisite for the utilization to tissue engineering because the metal surface must be controlled to induce the adhesion and proliferation of cells and the adsorption of essential biomolecules.

In this literature review, we will summarize the progress and the state-of-the-art of the metallic scaffolds as well as the reported biocompatibility of each of these metallic structures that has been conceived to be used in specific reconstruction of small or large bone defects. The design of a hard tissue-engineered scaffold logically begins with an intensive characterization of the host tissue properties. The properties of bone and how these apply to the design of a synthetic scaffold are discussed below.

\section{Bone Structure and Properties}

Bone is a natural composite material, which by weight contains about $45-60 \%$ minerals, $20-30 \%$ matrix, and 10-20\% water. By including the water fraction in the organic phase, the composition of bone can be simply represented as shown in Figure 1. The matrix is the organic component, which is primarily composed of the protein Type I collagen [2]. Type I collagen is a triple helix that is highly aligned, yielding a very anisotropic structure. The non-collagenous proteins are composed of noncollagenous glycoproteins and bone specific proteoglycans, these proteins include osteocalcin, osteonectin, bone phosphoproteins, bone sialoproteins and small proteoglycans [2]. The noncollagenous proteins have different functions in the regulation of bone mineralization and cell-tomatrix binding interactions with structural proteins. Less than $1 \%$ of the non-collagenous proteins contain growth factors influencing the cells but also secreted by them [3]. The cellular component is made of osteoblasts (bone-forming cells), osteoclasts (bone-destroying cells), osteocytes (bonemaintaining cells, which are inactive osteoblasts trapped in the extracelullar matrix) and bone lining cells (inactive cells that are believed to be osteoblasts precursors) [4]. The mineral, inorganic component of bone is a calcium phosphate known as Hydroxyapatite (HA). Hydroxyapatite has a chemical structure represented by the formaula $\mathrm{Ca}_{10}\left[\mathrm{PO}_{4}\right]_{6}[\mathrm{OH}]_{2}$ and is present in small crystallites 
form of approximately $2 \times 2 \times 40 \mathrm{~nm}^{3}$. These crystals undergo important changes in composition with age, thus their biologic functions depend on the amount and the age of the mineral crystals [5]. The inorganic matrix performs two essential functions as an ion reservoir and a structure giving the bone its stiffness and strength. In simple words, the organic matrix provides bone its flexibility and the inorganic material is predominantly responsible for the mechanical properties of bone [6,7].

The human skeleton can be categorized into two types of bone: the cortical bone and the trabecular bone. Although both bone types comprise the same composition, each one contains different proportions of the organic and inorganic materials, degree of porosity and organization. In addition, the combination of cortical and trabecular bone varies according the skeleton regions, which is dependent on the applied mechanical loading. Both, cortical and trabecular bones display timedependent mechanical behavior, as well as damage susceptibility during cyclic loading [8,9].

Despite the multiple functions bone has in the body, its biomechanical role is the most compromised upon injury. Indeed, the other bones in the body can compensate for the injured bone's metabolic function, but if a bone is broken or injured, it can no longer support the load it is meant for, and the body remains handicapped.

Figure 1. Chemical composition of bone tissue.

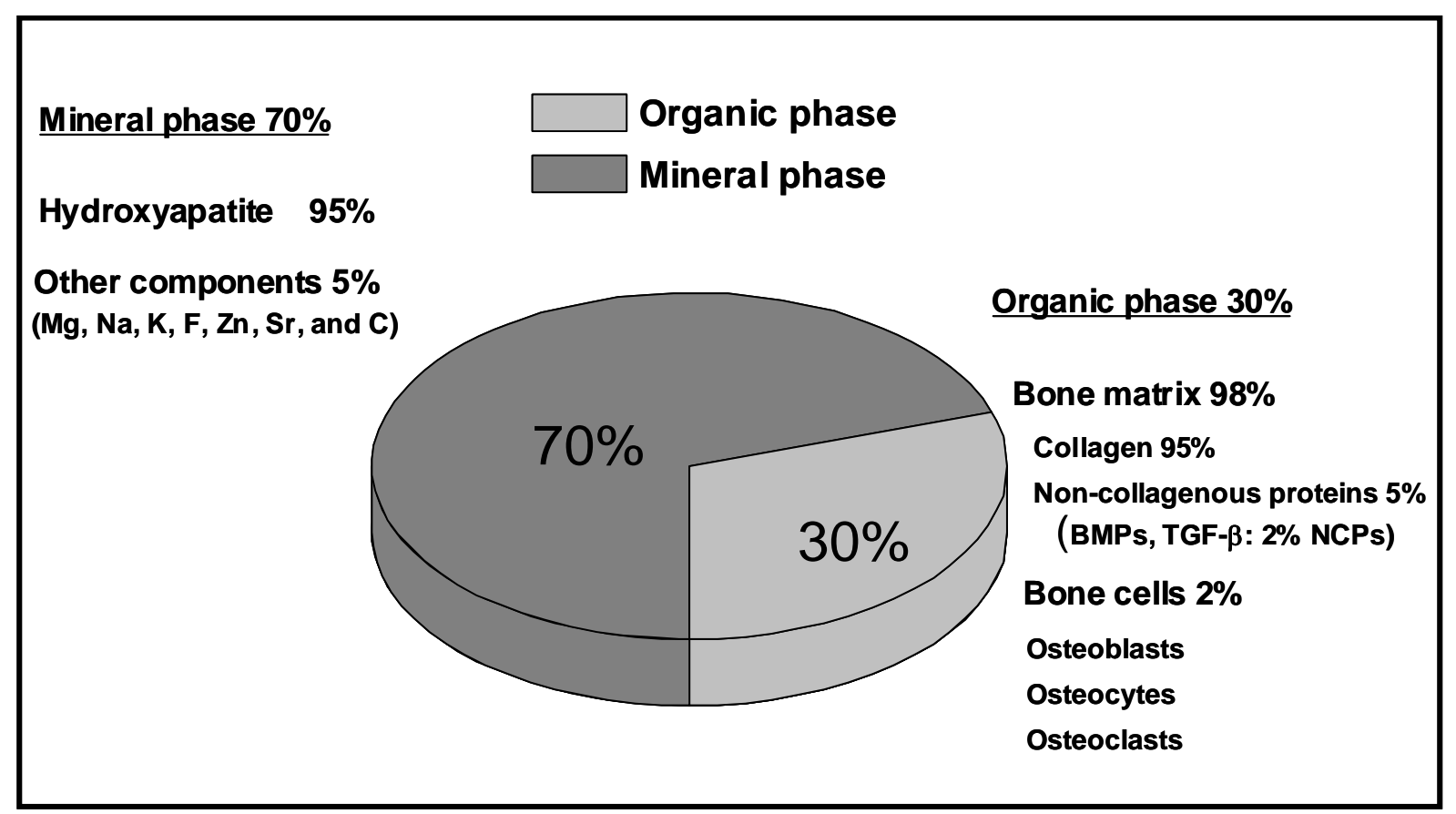

The mechanical properties of cortical bone have been well documented [10-13]. They can be measured via traditional testing techniques such as: uniaxial compressive or tensile testing, or three or four-point bending. Cortical bone exhibits a high degree of anisotropy and values of mechanical properties vary between animal species, bone location and testing conditions, age and disease. Testing conditions, for example, may vary between testing dry samples, testing wet samples at $37{ }^{\circ} \mathrm{C}$ and embedding them in an special resin or not.

Measuring properties of trabecular bone is far more complex than in the case of cortical bone as shown in Table 1. The complexity is due to the small dimensions of the individual trabeculae. When considered mechanically cortical and trabecular bone are not the same material. It is speculated that 
differences in moduli between cortical and trabecular bone are entirely due to the bone density. The range of cortical bone densities reported for the human proximal femur is $1.5-2 \mathrm{~g} / \mathrm{cm}^{3}$ [14] and the range of apparent trabecular bone density in human proximal femora is $0.2-0.6 \mathrm{~g} / \mathrm{cm}^{3}$ [15]. With either testing technique the mean trabecular Young's modulus is found to be significantly less than that of cortical bone. However, as can be seen in Table 1, some authors have found a value of elastic modulus of trabecular bone as high as those for cortical bone apparently because the test specimens were dried before the mechanical tests [12,16,18,19].

Mechanical properties of human bone depend dramatically on age; 3, 5, and 35-years old femoral specimens had a Young's modulus of 7.0, 12.8 and 16.7 GPa, respectively [20]. Besides age, the nutritional state, physical activity (mechanical loading), bone related diseases, etc., will influence the properties of bone tissue. This fact establishes a major challenge in the design and fabrication of scaffolds aimed to repair specific sites in specific patients.

Table 1. Mechanical properties of human cortical and trabecular bone.

\begin{tabular}{|c|c|c|c|}
\hline Cortical Bone & $\begin{array}{c}\text { Shear Strength } \times \\
10^{6} \mathrm{~N} / \mathrm{m}^{2} \\
\end{array}$ & $\begin{array}{l}\text { Strength } \\
\times 10^{6} \mathrm{~N} / \mathrm{m}^{2} \\
\end{array}$ & $\begin{array}{l}\text { Young's Modulus } \\
\text { range } \times 10^{9} \mathrm{~N} / \mathrm{m}^{2} \\
\end{array}$ \\
\hline Compression test & - & $\begin{array}{l}219 \pm 26 \text { Longitudinal } \\
153 \pm 20 \text { Transverse }\end{array}$ & $14.1-27.6$ \\
\hline Tensile test & - & $\begin{array}{c}172 \pm 22 \text { Longitudinal } \\
52 \pm 8 \text { Transverse }\end{array}$ & $7.1-24.5$ \\
\hline Torsional test & $65 \pm 9$ & - & - \\
\hline Ultrasonic method & - & - & $22-24.5$ \\
\hline Trabecular Bone & $\begin{array}{c}\text { Shear Strength } \times \\
10^{6} \mathrm{~N} / \mathrm{m}^{2} \\
\end{array}$ & $\begin{array}{l}\text { Strength range } \\
\quad \times 10^{6} \mathrm{~N} / \mathrm{m}^{2} \\
\end{array}$ & $\begin{array}{l}\text { Young's Modulus } \\
\text { range } \times 10^{9} \mathrm{~N} / \mathrm{m}^{2} \\
\end{array}$ \\
\hline Compression test & - & $1.5-9.3$ & $0.1-0.4$ \\
\hline Tensile test & - & $1.6-2.42$ & $10.4 \pm 3.5$ \\
\hline Torsional test & $6.35 \pm 2$ & - & - \\
\hline Ultrasonic method & - & - & $14.8 \pm 1.4$ \\
\hline
\end{tabular}

Compiled from references [10-13,17,19,21].

\section{Bone Tissue Engineering}

The goal of bone tissue engineering is to repair bone defects, which are difficult or even impossible to treat by conventional methods. This usually involves the use of 3-D bone graft substitutes to treat bone losses due to traumatic injury or revision surgery to augment the natural regenerative capacity of the body $[22,23]$. Bone tissue engineering employs a multidisciplinary approach, drawing on the principles of cell biology, molecular development biology, materials science and biomechanics, to aid in the repair of tissues damaged beyond the natural healing capacity of the bone. There are several approaches to bone engineering, ranging from inorganic bone fillers (in common clinical use) [24] to in situ bone induction by bone-inductive growth factors (in limited use) $[25,26]$ to laboratory cultured bone cells and gene therapy (in experimental phase) [27-29]. All these methods, however, have two 
common requirements: a physical continuity across the damage site that has to be provided to guide the bone growth, and the avoiding of scar formation.

In general, three essential elements are needed to successfully engineer a biological tissue or organ:

1) Tissue forming cells (osteogenic cells) and/or signaling biomolecules

2) Biocompatible scaffolds conducive to normal cell functions, and

3) Quantitative measures of tissue's regenerative outcome.

An ideal strategy for the tissue engineering of bone is the harvesting of osteogenic cells from the patient, which are then expanded in culture and seeded on a scaffold or graft that act as a guide and stimulus for tissue ingrowth in 3-D (Figure 2). Ideally, the need to regenerate tissue can be forecasted in advance, and cells taken from the patient can be seeded onto a scaffold, grown in vitro, and then reimplanted back into the patient, resulting in a healing of the damaged tissue. In a tissue-engineered scaffold, mesenchymal stem cells (MSCs) are usually included to give rise to bone cells. These stem cells can be readily extracted from the bone marrow of adult mammals (including humans), and can be induced to differentiate into natural tissue. The scaffold material can be preseeded in vitro with osteogenic cells to promote bone formation. At the implant site these cell/scaffold constructs contribute to bone formation.

Figure 2. Tissue-engineered graft fabrication process.

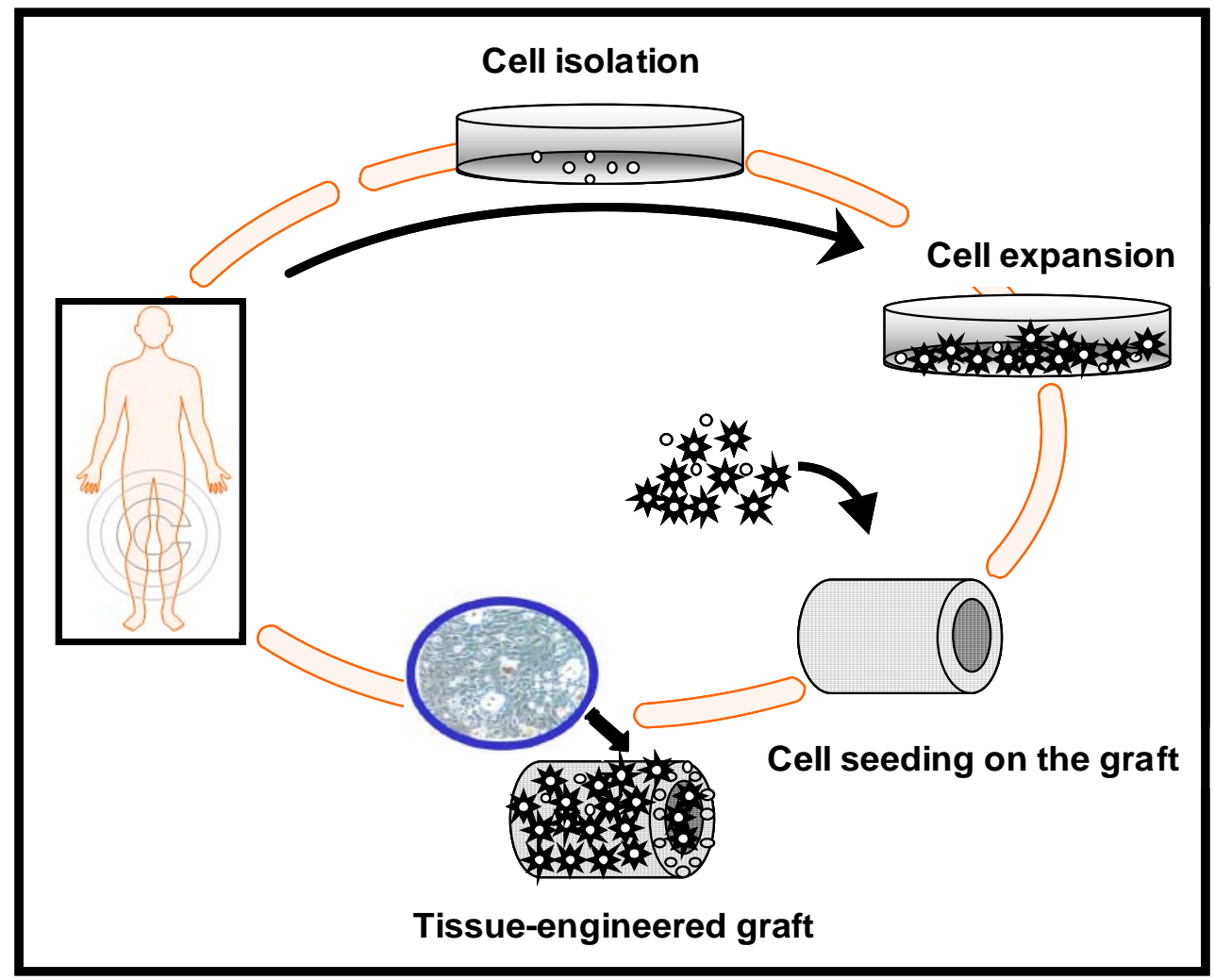

The role of the scaffold is to act as a carrier that restricts the movement of these MSCs cells away from the implantation site and to provide support for new bone formation. Figure 3 schematically illustrates the cell-based strategy for tissue regeneration. The osteogenic cells lay down bone extracellular matrix in the surface of the scaffold as woven immature bone. Over time, a mature bone 
structure will form inside and in the exterior part of the scaffold allowing the regeneration of the tissue.

Figure 3. Cell-based tissue regeneration approach for the repair of bone defects.

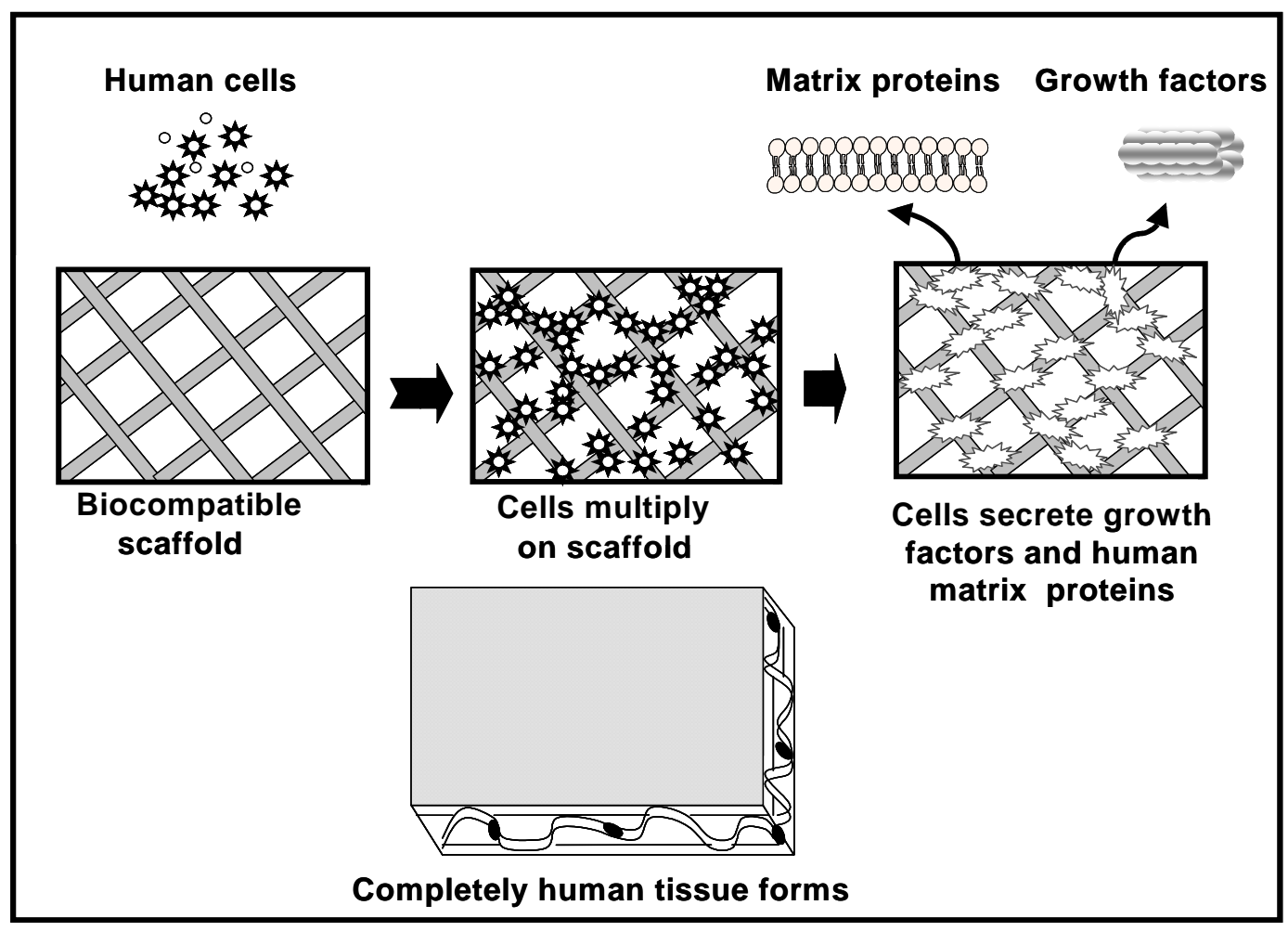

Growth factors such as basic fibroblasts growth factors (FGFs), platelet-derived growth factor (PDGF), insulin-like growth factor (IGF), epidermal growth factor (EPG), transforming growth factorbeta (TGF- $\beta$ ), bone morphogenetic proteins (BMPs), etc., also would be applied in the tissue engineered scaffolds to promote bone formation. When the scaffold material is loaded with specific bone-inductive growth factors, these exogenous growth factors are then released at the implantation site, where they can act upon locally resident cells as well as recruiting other more distant cells to form new bone tissue. Bone morphogenetic proteins are active bone-inducing factors that act on immature mesenchymal cells, including osteoblasts, resulting in osteogenesis [30]. To date, molecular cloning has isolated several types of BMPs, and recombinant BMP molecules have been synthesized [31]. BMPs 2, 4, 6, and 7 are generally considered to be the most osteoconductive of the bone morphogenetic proteins. BMP-2, specifically promotes undifferentiated mesenchymal cells into osteoblasts, leading to bone formation [32].

While these factors place special demands on all aspects of tissue engineering, scaffold design takes on a role of particular importance. We will discuss this topic separately in the following section.

Finally, postoperatively high quality image examinations are required to investigate the effectiveness of the implantation such as the position of the scaffold and evaluate the developing status of surrounding anatomic structures. For the clinical determination of the bone ingrowth inside the scaffold recently advances of the X-ray micro-computed tomography $(\mu \mathrm{CT})$ imaging have shown sufficient resolution for the accurate identification of the bone ingrowth within the metallic porous structure. However, the complex process of bone remodeling inside a tissue-engineered construct, 
made up of scaffold material, host bone, mineralized bone and soft tissue, makes the partitioning of the tomogram into discrete phases non-trivial [33]. In the past, $\mu \mathrm{CT}$ was not suitable for metallic scaffolds as the metal heavily attenuates X-rays. The presence of metal resulted in dark and bright grainy artifacts, which obscure important details of the scan images [34]. However, improved algorithms for metal artifact reduction has been developed recently [35,36], and the combination of 2 mm thick aluminum filter and a $10 \mathrm{~mm}$ thick polymethylmethacrylate filter has been employed improving the signal-to-noise ratio in the images. By doing this it can be reduced the streak artifacts caused by the metallic material [37].

\section{General Desirable Properties of the Bone Scaffolds}

A scaffold for hard tissue reconstruction is a three dimensional construct, which is used as a support structure allowing the tissues/cells to adhere, proliferate and differentiate to form a healthy bone/tissue for restoring the functionality. In almost all the clinical cases, scaffolds for hard tissue repair in a load-bearing area are not temporary, but permanent. They most retain their shape, strength and biological integrity through the process of regeneration/repair of the damaged bone tissue. Bone replacement constructs for bone defects reconstructions would need to be biocompatible with surrounding tissue, radiolucent, easily shaped or molded to fit perfectly into the bone defect, nonallergic and non-carcinogenic, strong enough to endure trauma, stable over time, able to maintain its volume and osteoconductive (able to support bone growth and encourage the ingrowth of surrounding bone) [38-42].

Apart from the above-mentioned material requirements, the structural requirements expected for the possible candidate for bone scaffold are numerous, ranging from the maximum feasible porosity to the porous architecture itself. Pore size and interconnectivity are important in that they can affect how much cells can penetrate and grow into the scaffold and what quantity of materials and nutrients can be transported into and out of the scaffold. In other words, pore size distributions, porosity and the interconnectivity of the scaffold should be sufficient for cell seeding, cell migration, matrix deposition, vascularization and mass transport of nutrients from and to the cells. Physiologically, previous research has shown that the optimum pore size for promoting bone ingrowth is in the range of 100-500 $\mu \mathrm{m}$ [43-45]. However, the scientific community has not reached yet a consensus regarding the optimal pore size for bone ingrowth.

From a mechanical perspective, scaffold materials aimed for the repair of structural tissues should provide mechanical support in order to preserve tissue volume and ultimately to facilitate tissue regeneration. The most critical mechanical properties to be matched by the scaffold are bone loading stiffness, strength and fatigue strength. When the scaffold's stiffness exceeds that of natural bone, stress concentration in the surrounding bone can cause bone failure. Conversely, when the scaffold's stiffness is less than that of natural bone, stress concentration in the scaffold can cause implant failure as well as bone atrophy. This effect of stiffness mismatch, which gives rise to uneven load sharing between bone and implant, is known as stress shielding [46]. Stress shielding affects the bone remodeling and healing process. The underloaded bone adapts to the low stress environment and becomes less dense and consequently weak. In addition to matching bone stiffness, the scaffold should also match or exceed the strength of natural bone. The scaffold must resist physiological forces within 
the implantation site and should have sufficient strength and stiffness to function for a period until in vivo tissue ingrowth has filled the scaffold matrix. An equal or excess strength ensures that the scaffold has equivalent or better load bearing capabilities than natural bone. For last, for a nonresorbable scaffold, it is very important to consider the fatigue strength, since the scaffold will be exposed to cyclic loading during the rest of the patient's life. Complete design of the scaffold must take into account both the mechanical considerations and the biological requirements to produce a globally optimized structure with an adequate chemical composition able to allow the subsequent ingrowth of bone.

In the scaffold design, surface properties including: topography, surface energy, chemical composition, surface wettability, surface bioactivity, etc., must all be considered, taking into account that in a complex porous 3-D scaffold the surface is not just the outside surface, but also the internal 3-D surfaces. For example, the modification of scaffolds materials with bioactive molecules is a technique to tailor the scaffold bioactivity. In addition, reduction of micromotion can be obtained by appropriately tailoring the material surface of the scaffold. The development of the required interface is not only highly influenced by surface chemistry, but also more specifically by nanometer and micrometer scale topographies. The surface roughness is found to influence the cell morphology and growth. It has been proved that alteration in surface topography by physical placement of grooves and depressions changes the cell orientation and attachment [47-48]. In general, smooth surfaces exhibit less cell adhesion than rough surfaces. On the other hand, surface porosity is another important factor in bone replacement [49-50]. It has been reported that materials coated with a porous surface exhibit less fibrous capsule formation than bulk or non-porous materials [51].

Surface modifications, such as, immobilization of biofunctional polymers and biopolymers, calcium phosphate ceramic coatings, hybridization with biocompatible and essential biomolecules are needed to achieve the required tissue induction properties. Countless procedures have been developed to modify the surface of biomaterials. Table 2 shows an overview of the surface modification methods available for titanium and its alloys. It has been widely demonstrated that surface treatment of titanium and its alloys has a critical influence on biocompatibility.

Table 2. Surface modification techniques available for pure titanium and titanium alloys. Modified from Liu X. et al. [52].

\begin{tabular}{|c|c|c|c|}
\hline & Surface modification techniques & Modified layer & Purpose \\
\hline \multirow{8}{*}{$\begin{array}{l}\text { Mechanical } \\
\text { Methods }\end{array}$} & Machining / Electrochemical & Smooth surfaces; roughness $\left(R_{\mathrm{a}}\right): 0.1 \mu \mathrm{m}$ & All the mechanical methods are able to \\
\hline & micromachining (EMM) & or less. & produce a good surface finish, alter the \\
\hline & & & native oxide layer and generate specific \\
\hline & Grinding & Macro-rough or micro-rough surfaces; & topographies leading to improve the \\
\hline & Mechanical polishing & roughness $\left(R_{\mathrm{a}}\right): 0.5-6 \mu \mathrm{m}$. & biological fixation. \\
\hline & Polishing media: $\mathrm{SiC}, \mathrm{Al}_{2} \mathrm{O}_{3}$, diamond & & \\
\hline & Grit-blasting & Depressions, gouges produced by plastic & \\
\hline & e.g. $\mathrm{Al}_{2} \mathrm{O}_{3}, \mathrm{SiO}_{2}, \mathrm{ZrO}_{2}, \mathrm{TiO}_{2}$, etc. & deformation. & \\
\hline
\end{tabular}


Table 2. Cont.

\begin{tabular}{|c|c|c|c|}
\hline Physical & Physical vapor deposition (PVD) & & Decrease erosive and abrasive wear rates, \\
\hline \multirow[t]{15}{*}{ Methods } & Evaporation & $\int \sim 0.02$ to $1 \mu \mathrm{m}$ single or multi-coating layer & improve corrosion resistance and improve \\
\hline & Ion plating & of TiC, $\mathrm{TiN}, \mathrm{TiC} / \mathrm{TiB}_{2}$, TiCN and & hemocompatibility. \\
\hline & Reactive sputtering & diamond-like carbon, among others. & \\
\hline & Ion implantation and deposition & $<50 \mathrm{~nm}$ of surface modified layer. & Modify the surface composition by \\
\hline & & & incorporation of ionic groups improving the \\
\hline & Plasma immersion ion implantation and & $<150 \mathrm{~nm}$ of surface modified layer. & surface bioactivity and bone conduction. \\
\hline & deposition (PIII\&D) & & Surface topography can be altered. Improve \\
\hline & Beam-line ion implantation & < $1500 \mathrm{~nm}$ of surface modified layer. & wear and corrosion resistance. \\
\hline & $\begin{array}{l}\text { Glow-discharge plasma treatment } \\
\text { (GDP) }\end{array}$ & $20 \mathrm{~nm}$ to $2 \mu \mathrm{m}$ of surface modified layer. & $\left\{\begin{array}{l}\text { Clean, sterilize and remove the native oxide } \\
\text { layer. Can produce a nitrided surface. }\end{array}\right.$ \\
\hline & Thermal spray & & \\
\hline & Flame spray (FLSP) & & Modify the surface structure and \\
\hline & Plasma arc spray (PSP) & $\sim 10$ to $200 \mu \mathrm{m}$ of coatings of & composition. Improve wear and corrosion \\
\hline & High velocity oxygen fuel (HVOF) & hydroxyapatite (HA), $\mathrm{TiO}_{2}, \mathrm{Al}_{2} \mathrm{O}_{3}, \mathrm{ZrO}_{2}$ & resistance and biocompatibility. \\
\hline & Detonation gun (D-Gun) & $\mathrm{CaSiO}_{3}$, etc. & \\
\hline & Electric arc spray (EASP) & & \\
\hline \multirow{21}{*}{$\begin{array}{l}\text { Wet } \\
\text { Chemical } \\
\text { Methods }\end{array}$} & Biomimetic method & Bone-like apatite precipitates are formed & Improve biocompatibility. \\
\hline & & from a simulated body fluid (SBF), $<50 \mu \mathrm{m}$ & \\
\hline & & & \\
\hline & Acid etching & $<10 \mathrm{~nm}$ of surface modified layer. & Remove native oxide film and \\
\hline & e.g. $\mathrm{HNO}_{3}-\mathrm{HF}, \mathrm{HCl}, \mathrm{H}_{2} \mathrm{SO}_{4}$ & & contamination. Produce sub-micron porosity \\
\hline & Alkali-and heat-treatment & $\sim 1 \mu \mathrm{m} \mathrm{NaTiO}{ }_{3}$ hydrogel layer. & Induced roughness on a micrometer scale, \\
\hline & Dual treatment (acid + alkaline) & & enhance the biomimetic coating capacity and \\
\hline & & & the bone-bonding ability \\
\hline & Hydrogen peroxide treatment & $10 \mathrm{~nm}$ surface layer containing hydrated & Clean the surface, alter surface topography \\
\hline & & oxide, peroxide and superoxide. & and induce bioactivity to the surface. \\
\hline & Sol-gel process & $\sim 30 \mu \mathrm{m}$ homogeneous and adherent thin & Thicker and denser films with a special \\
\hline & & films of $\mathrm{TiO}_{2}, \mathrm{CaPO}_{4}, \mathrm{SiO}_{2}$, etc. & topography to improve the biocompatibility. \\
\hline & Electrophoresis & $<10 \mu \mathrm{m}$ of surface modified layer. & Induce bioactivity to the surface, improve \\
\hline & Electrophoretic deposition (EPD) & & biocompatibility. \\
\hline & Immobilization of functional groups & $\sim 10 \mu \mathrm{m}$ to $15 \mu \mathrm{m}$ of calcium phosphate & Induce bioactivity to the surface, improve \\
\hline & (i.e. $-\mathrm{SO}_{3} \mathrm{H},-\mathrm{PO}_{4} \mathrm{H}_{2},-\mathrm{COOH}$ via SAMs & films. & biocompatibility. \\
\hline & to $\mathrm{Ti}$ ) & & \\
\hline & Electrochemical anodic oxidation & $\sim 10 \mathrm{~nm}$ to $50 \mu \mathrm{m}$ of $\mathrm{TiO}_{2}$ layer, with the & Increases the thickness of the oxide layer \\
\hline & Anodic spark deposition (ASD) & adsorption and/or incorporation of ions (S, & producing a micro porous structure. \\
\hline & & $\mathrm{P}$, or $\mathrm{Ca} / \mathrm{P})$. Nano to micrometer $\mathrm{TiO}_{2}$ & Improves bioactivity, and corrosion \\
\hline & & layer. & resistance. \\
\hline \multirow{5}{*}{$\begin{array}{l}\text { Chemical } \\
\text { Methods }\end{array}$} & Thermal oxidation & $\sim 20 \mathrm{~nm}$ to $1 \mu \mathrm{m}$ of $\mathrm{TiO}_{2}$ layer. & Produces a thick layer of $\mathrm{TiO}_{2}$ with a \\
\hline & & & morphologically rugged surface. \\
\hline & Chemical vapor deposition (CVD) & $\sim 1$ to $5 \mu \mathrm{m}$ single or multi-coating layer of & Decrease erosive and abrasive wear rates, \\
\hline & Plasma-enhanced CVD & $\mathrm{TiO}_{2}, \mathrm{TiO}_{x}, \mathrm{TiC}, \mathrm{TiN}, \mathrm{TiCN}$ and diamond- & improve corrosion resistance and improve \\
\hline & & like carbon, among others. & hemocompatibility. \\
\hline
\end{tabular}

SAMs: Self-assembled monolayers. 
On the other hand, to program scaffolds with biological structures, cells and growth factors need to be integrated into the scaffold fabrication for bone tissue engineering, so that the bioactive molecules can be released from the scaffold in order to stimulate or modulate new tissue formation. Through surface modifications the metallic scaffold surface can be tailored to improve the adhesion of cells and adsorption of biomolecules in order to stimulate the bone formation and to facilitate faster healing [53]. Currently, a significant research effort is aimed at the biochemical modification of metallic surfaces. Table 3 presents some of the biochemical methods for surface modification of scaffolds introduced in recent years. The goal of the biochemical surface modification is to immobilize proteins, enzymes or peptides on biomaterials for the purpose of inducing specific cell and tissue responses, or in other words, to control the tissue-scaffold interface with molecules delivered directly to the interface. Nowadays, for the regeneration of structural tissues the bone tissue engineering is focusing in the development of a common framework for designing and building porous structures having both materials and biological components.

Table 3. Biochemical surface modification methods available for bone scaffolds.

\begin{tabular}{|c|c|c|c|}
\hline & Surface modification techniques & Modified layer & Purpose \\
\hline Biochemical & Modification through biological polymers: & $\sim 10 \mathrm{~nm}$ to $5 \mu \mathrm{m}$ of surface modified & Induce specific cell and tissue response, \\
\hline \multirow[t]{9}{*}{ Methods } & collagen, fibrin, peptides, alginates, chitosan, & layer. & enhancing the osseointegration. \\
\hline & hyaluronic acid, etc. & & \\
\hline & Modification through synthetic polymers: PLA, & $\sim 10 \mathrm{~nm}$ to $1 \mu \mathrm{m}$ of surface modified & Used as carriers of growth factors for \\
\hline & PGA, PCL, PC, etc. & layer. & local drug delivery. \\
\hline & Biochemical factors or other inductive signaling & $\sim 10 \mathrm{~nm}$ to $1 \mu \mathrm{m}$ of surface modified & Stimulate fracture healing and bone \\
\hline & molecules or drugs incorporation & layer. & mineralization. \\
\hline & Autologous or allogenic bone marrow cells & $\sim 20 \mu \mathrm{m}$ to $50 \mu \mathrm{m}$ of surface modified & Impart osteogenic capacity by providing \\
\hline & Autologous or allogenic platelet concentrate & layer. & an environment that mimics that of the \\
\hline & Mesenchymal stem cells & & ECM. \\
\hline
\end{tabular}

PLA: polylactic acid; PGA: polyglycolic acid; PCL: polycaprolactone; PC: polycarbonate; ECM: Extracellular matrix.

In summary, the hybridization with active biofactors (cells, genes and/or proteins), the chemical composition, and the topography (structure, morphology) of the scaffold surface are known to be extremely important in bone replacement, since they regulate the type and degree of the interactions that take place at the interface: adsorption of ions and biomolecules such as proteins; formation of calcium phosphate layers; or interaction with different type of cells (macrophages, bone marrow cells, osteoblasts, etc.) [54,55]. For this reason, in recent years there has been a lot of research effort aimed at optimizing and controlling surface properties of the bone scaffolds with a view to customizing a certain material for the required application.

Equally important for the success of the loading-bearing scaffold is the postoperative stability. The scaffold and the surrounding bone must be tightly apposed to ensure osteointegration. In order to achieve stability over the time the scaffold must fulfill each patient anatomical requirement. Anatomically, the external geometry and size of the scaffold should be the same as those of the tissue defect in order for the scaffold to fit and anchor into the defect site. Computed-aided tissue engineering enables the application of advanced computer aided technologies and biomechanical 
engineering principles to derive systematic solutions for the designing and fabrication of patientspecific scaffold [56].

Finally, the scaffold for bone repair should be easy to manufacture with highly consistent pore sizes, pore distribution, pore density and interconnectivity with a narrow size distribution range of the structural parameters over the entire volume of the scaffold [57]. And for last, the scaffold must withstand sterilization procedures without loss of properties and have an acceptable shelf-life.

\section{Currently Used Metallic Scaffolds Materials and Their Limitations}

To date there are several biocompatible metallic materials that are frequently used as implanting materials in dental and orthopedic surgery to replace damaged bone or to provide support for healing bones or bone defects. Standard surgical implant materials include stainless steel 316 L (ASTM F138), Co based alloys (mainly ASTM F75, and ASTM F799) and titanium alloys; where Ti-6Al-4V (ASTM F67 and F136) are the most employed. However, the main disadvantage of metallic biomaterials is their lack of biological recognition on the material surface. To overcome this restraint, surface coating or surface modification presents a way to preserve the mechanical properties of established biocompatible metals improving the surface biocompatibility. Moreover, in order to enhance communication between cells, facilitating their organization within the porous scaffold; it is desired to integrate cell-recognizable ligands and signaling growth factors on the surface of the scaffolds. Indeed, biofactors that influence cell proliferation, differentiation, migration, morphologies and gene expression can be incorporated in the scaffold design and fabrication to enhance cell growth rate and direct cell functions [58]. Another limitation of the current metallic biomaterials is the possible release of toxic metallic ions and/or particles through corrosion or wear possible that lead to inflammatory cascades and allergic reactions, which reduce the biocompatibility and cause tissue loss [59]. A proper treatment of the material surface may help to avoid this problem and create a direct bonding with the tissue.

On the other hand, depending on the materials properties, some metallic materials are too weak to be arranged into the desired architecture with a controlled porous structure and some metals are too stiff and would fracture when arranged into certain architectures. Each metallic material possesses different processing requirements and the degree of processability of each metal to form a scaffold is variable also.

\subsection{Tantalum}

Porous tantalum is a biomaterial with a unique set of physical and mechanical properties. It has a high-volume porosity ( $>80 \%$ ) with fully interconnected pores to allow secure and rapid bone ingrowth [60]. In addition, it has a modulus of elasticity similar to that of bone, which minimizes stressshielding. Porous tantalum is a structural material and has sufficient strength to allow physiological load-carrying applications and represents an alternative metal for primary and revision total knee arthroplasty (TKA) with several unique properties. Bobyn and coworkers [60,61] presented basic scientific data that lend support for the use of this material, which is a trabecular metal composed of a carbon substrate that has elemental tantalum deposited on the surface. This trabecular metal has been 
shown to be highly biocompatible in several animal models [60,61,133]. Studies have demonstrated substantial cortical bone ingrowth between the trabecular network as well as high levels of bone growth onto the scaffold itself. Initial stability of the trabecular metal itself is also higher than that of standard materials, such as cobalt chrome. Furthermore, this new material offers better osteoconduction than other technologies used for biological fixation. Although porous tantalum is in its early stages of evolution, the initial clinical data [135-138] and preclinical studies [178-185] support its use as an alternative to traditional orthopedic implant materials.

\subsection{Magnesium}

The use of magnesium and its alloys for surgical applications is of particular interest. These alloys have great potential, and it has been shown that they are fully bioresorbable, have mechanical properties aligned to bone, induce no inflammatory or systemic response, are osteoconductive, encourage bone growth, and have a role in cell attachment [62]. Furthermore, because of its biodegradability, the second surgery for the removal of the scaffold might be avoided. All these facts suggest that $\mathrm{Mg}$ has significant potential as a load-bearing biomaterial. Indeed, there is a renewed interest in the use of this material in biomedical applications, e.g. for coronary stents [63,64], and more recently, researchers have concentrated on the application of magnesium-rare-earth alloys with new elemental contributions of cerium, neodymium and praseodymium for bone fixation devices [65,66] for osteo-applications. Recently, Mg-Ca alloys have been also produced and evaluated in vitro and in vivo as biodegradable biomaterials for orthopedic applications [67]. However, concerns over the toxicity of dissolved $\mathrm{Mg}$ have been raised, but it has been shown that the excess of magnesium is efficiently excreted from the body in urine [68]. In addition, concern does remain over the use of pure $\mathrm{Mg}$ as the dissolution rate in physiological conditions is rapid, potentially leading to hyper-magnesia, although a number of potential routes to controlling the corrosion rate have been proposed; especially providing it with a ceramic coating [69], titanium coating [70] or through the use of $\mathrm{Mg}$ alloys, including AZ31, AZ91, WE43, LAE442 and Mg-Mn-Zn alloys [65,66,71]. Although limited long-term survival data is available for $\mathrm{Mg}$ or $\mathrm{Mg}$ alloys porous scaffolds, the material seems promising for certain bone ingrowth applications such as trabecular bone regeneration.

\subsection{Titanium and Titanium Alloys}

Titanium is found to be well tolerated and nearly an inert material in the human body environment. In an optimal situation titanium is capable of osseointegration with bone [72]. In addition, titanium forms a very stable passive layer of $\mathrm{TiO}_{2}$ on its surface and provides superior biocompatibility. Even if the passive layer is damaged, the layer is immediately rebuilt. In the case of titanium, the nature of the oxide film that protects the metal substrate from corrosion is of particular importance and its physicochemical properties such as crystallinity, impurity segregation, etc., have been found to be quite relevant. Titanium alloys show superior biocompatibility when compared to the stainless steels and Cr-Co alloys. Titanium-aluminum-vanadium alloys (ASTM F136, ASTM F1108 and ASTM F1472) have better mechanical properties than commercially pure titanium (cp Ti) (ASTM F67) and are used more widely in total joint implants. However, concerns have been expressed about the 
presence of long-term Ti-6Al-4V implants, because elements such as vanadium are toxic in the elemental state. These concerns have led to the development of new beta titanium alloys with nontoxic alloying elements like $\mathrm{Ta}, \mathrm{Nb}, \mathrm{Zr}$ [73]. Other currently available titanium alloys include ASTM F1295 (wrought Ti-6Al-7Nb alloy), ASTM F1713 (wrought Ti-13Nb-13Zr alloy), ASTM F1813 (wrought Ti-12Mo-6Zr-2Fe alloy) and ASTM F2066 (wrought Ti-15Mo alloy) and Ti-5Al-2.5Fe (ISO 5832-10). Further biocompatibility enhancement and lower modulus has been achieved through the introduction of second generation titanium orthopedic alloys including Ti-15Mo-5Zr-3Al, Ti-15Zr4Nb-2Ta-0.2Pd, Ti-12Mo-6Zr-2Fe, Ti-15Mo-3Nb-3O and Ti-29Nb-13Ta-4.6Zr. This new generation of $\mathrm{Ti}$ alloys is at present under development and investigation, and it does not seem to be commercialized yet. In general, porous titanium and titanium alloys exhibit good biocompatibility. Bioactive titanium meshes have been successfully used in spine fusion surgery for the past two decades [74]. The titanium mesh cage contoured into cylindrical shape has been used successfully for anterior lumbar interbody fusion (ALIF) for more than 15 years in surgery. Titanium mesh cages were also used with autografts for bone grafting in spinal fusion. This is restricted by factors such as complications and second site morbidity [74]. One method to overcome this problem is the use of hydroxyapatite to provide the necessary bioactivity to the titanium mesh cage with a porous network to facilitate osteoconduction [196,199]. Moreover, despite the great advances in complete tissue engineered oral and maxillofacial structures, the current gold standard for load bearing defect sites such as mandible, maxilla and craniofacial reconstruction remains titanium meshes and titanium 3-D scaffolds. On the other hand, Ti and its alloys are not ferromagnetic and do not cause harm to the patient in magnetic resonance imaging (MRI) units. Titanium osseointegration can be potentially improved by loading the scaffold with specific growth factors. In applications where there are existing gaps, such as craniofacial reconstruction or augmentation of bone or peri-implant defects, increased regeneration of bone, often has been accomplished with delivery of TGF- $\beta$ and BMP-2 via titanium scaffold $[30,75]$. The latter growth factors are capable to elicit specific cellular responses leading to rapid new tissue formation. Stem cells have also been cultured in vitro onto titanium scaffolds [76] to induce the formation of calcified nodules in order to increase the production of mineralized extracellular matrix (ECM) onto the cells/scaffold constructs.

\subsection{Nickel-Titanium Alloy (Nitinol)}

Nitinol is one of the most promising titanium implants that find various applications as it possesses a mixture of novel properties, even in a porous state, such as shape memory effect (SME), enhanced biocompatibility, superplasticity, and high damping properties [77,78]. Since the elastic modulus of the Nitinol foams ( 2.3 GPa) and the compressive strength ( $208 \mathrm{MPa})$ are close to that of the bone and due its good biocompatibility porous NiTi have been used in making intramedullary nails and spinal intervertebral spacers used in the treatment of scoliosis [79]. Extensive in vivo testing and preclinical experience indicates that Nitinol is highly biocompatible, more than stainless steels $[79,80]$. Moreover, good biocompatibility on surface modified NiTi has been reported [81-84]. The demonstrated biocompatibility of Nitinol, its physical properties and SME, suggest that this alloy may offer substantial gains in the orthopedic field. These gains revolve around creating scaffolds that change shape after implantation due to the SME of Nitinol that can be initiated at the temperature of 
the human body. However, there is a problem of allergy and toxicity for NiTi alloys associated with the release of $\mathrm{Ni}$ ions. The concern of $\mathrm{Ni}$ toxicity and potential carcinogenicity has limited the use of NiTi alloys in Europe and the USA. In order to overcome this problem, surface modifications such as oxidation treatment of NiTi to obtain a Ni-free surface [85] and several alternative Ni-free shape memory alloys, mainly Nb-based, are currently under development although their long-term biological performance will have to be assessed in the future [86].

\subsection{Hybrid Materials}

Hybrid materials are those in which more than one class of material is employed in the scaffold. Today there are many different types of materials combinations principally used in artificial joints and bone implants. Many combinations of materials and surface modifications are aimed to stimulate specific responses at the molecular level. The synergistic combination of two types of materials may produce new structures that possess novel properties.

Common material combinations are synthetic polymer with bio-ceramic and synthetic/natural polymers with metals. Novel metal-ceramic-polymer hybrid materials have also been proposed for the fabrication of load-bearing scaffolds. In many clinical cases, composite scaffolds may prove necessary for reconstruction of structural diseases and bone defects. Nevertheless, the mechanical property requirements for hard tissue repair are difficult to satisfy using porous polymer/ceramic composites. Particularly, scaffolds based on HA or tricalcium phosphates (TCP) are very stiff, maybe brittle and may have different viscoelastic properties from bone [87]. To assure the mechanical integrity, hybrid constructs of porous Ti/TCP ceramic and cells have been tried and have demonstrated better osteogenic properties compared with Ti scaffold alone after implantation in goats [150]. Porous Ti is usually combined with bone inductive materials or cells, which endow the osteoinductive property leading to a rapid bone healing.

\section{3-D Metallic Scaffolds Fabrication Technologies}

Numerous fabrication techniques have been developed for the production of 3-D metallic scaffolds of high porosity and surface area for load-bearing applications. The basic goal of the available manufacturing techniques is to produce a micro-architecture in a scaffold that is highly porous to allow for cell adhesion, vascularization and nutrient flow. Mechanical considerations however, limit the range of porosities at the optimum pore size that can be employed to produce functional structures. Strength and ductility of porous structures are very sensitive to final density, pore size, material type, and fabrication parameters. Metallic scaffolds can be produced in a variety of ways, using conventional techniques or advanced processing methods. The choice of the technique depends on the requirements of the final application. Selection of the scaffold material and design, the method by which to construct them, and the possible additional surface modification are important to the success of using the scaffold to regenerate new bone. 


\subsection{Conventional Fabrication Methods}

Conventional methods for manufacturing metallic scaffolds include sintered metal powders [88], sintered metal fibres [89], space-holder method [90], replication of polymeric sponge [91], fiber meshes and fiber bonding [92], self propagating high temperature synthesis (SHS) [93], spark plasma sintering (SPS) [94] or field assisted consolidation technique (FAST) [95], gas injection into the metal melt [96], decomposition of foaming agents [97-99], templated vapor deposition [60] and solid-state foaming by expansion of argon-filled pores [100]. However, there are inherent limitations in these processing methods, which offer little capability to control precisely pore size, pore geometry, pore interconnectivity, spatial distribution of pores, porosity, etc. As a result, there are really few manufacturing technologies capable of producing porous structures that possess the majority of the desired requirements. Moreover, the manufacturing of porous titanium and its alloys is associated with some difficulties; most notably the extreme chemical affinity of liquid titanium to atmospheric gases such as oxygen, hydrogen, and nitrogen, which eventually leads to strongly reduced ductility [101]. Table 4 shows a comparison between the different conventional fabrication methods that have been applied to produce metallic porous structures.

Table 4. Comparison of various conventional fabrication methods for manufacturing metallic porous scaffolds. Numbers in parentheses correspond to the typical porosity $(\varepsilon)$ values that each method is able to achieve. Modified from Ryan G. et al. [100].

\begin{tabular}{|c|c|c|c|c|}
\hline & Closed-cell porosity & & Open-cell porosity & \\
\hline $\begin{array}{l}\text { Random pore } \\
\text { distribution }\end{array}$ & & Porosity gradient & Non-homogeneous & Homogeneous \\
\hline $\begin{array}{l}\text { Gas injection into the } \\
\text { metal melt [96] }\end{array}$ & & $\begin{array}{l}\text { Spark plasma sintering } \\
\text { (SPS) [94] }\end{array}$ & $\begin{array}{l}\text { Sintered metal } \\
\text { powders [88] }\end{array}$ & $\begin{array}{l}\text { Fiber meshes sintering [92] } \\
(\varepsilon \leq 90 \%)\end{array}$ \\
\hline$(\varepsilon=10-75 \%)$ & & $(\varepsilon=50-60 \%)$ & $(\varepsilon=20-90 \%)$ & $\begin{array}{l}\text { Fiber bonding [173] } \\
\text { ( } \varepsilon \leq 70 \%)\end{array}$ \\
\hline $\begin{array}{l}\text { Decomposition of } \\
\text { foaming agents }\end{array}$ & $\begin{array}{l}\text { Metallic precursors }[97,98] \\
\text { ( } \varepsilon \leq 80 \%) \\
\text { Ceramic precursors [99] } \\
(\varepsilon=40-80 \%)\end{array}$ & $\begin{array}{l}\text { Field assisted } \\
\text { consolidation technique } \\
\text { (FAST) [95] } \\
(\varepsilon=50-60 \%)\end{array}$ & $\begin{array}{l}\text { Sintered metal fibers [89] } \\
(\varepsilon=20-80 \%)\end{array}$ & $\begin{array}{l}\text { Templated vapor } \\
\text { deposition [60] } \\
(\varepsilon=80-95 \%)\end{array}$ \\
\hline $\begin{array}{l}\text { Gas entrapment [100] } \\
(\varepsilon=45-55 \%)\end{array}$ & & & $\begin{array}{l}\text { Space-holder method [90] } \\
\text { ( } \varepsilon \leq 70 \%) \\
\text { Replication [91] } \\
\text { ( } \varepsilon=80-95 \%) \\
\text { Self propagating high } \\
\text { temperature synthesis (SHS) } \\
\text { [93] } \\
(\varepsilon \leq 50 \%)\end{array}$ & \\
\hline
\end{tabular}

${ }^{*}$ Larger pores near the surface and smaller pores far form the surface.

The porous structure of the closed-cell structures is equiaxed and pores are surrounded by a metallic wall. In contrast, open-cell structures incorporate interconnected pores. Porous metals with elongated 
pores aligned in one direction-lotus structures — have recently been described also [96,98]. Scaffolds fabricated using conventional technologies have been employed clinically. Sintered bead coatings have been developed commercially using cobalt chrome and titanium alloys and have been shown to produce a durable biological bond that may last over ten years post implantation [103-106]. Diffusion bonded fiber-mesh porous structures have also been shown to successfully promote long-term implant fixation [107-110]. However, the maximum porosities attainable using these technologies is less than $50 \%$ at the required $100-700 \mu \mathrm{m}$ pore sizes [111].

\subsection{Rapid Prototyping (RP) Technology}

In early 1980s, rapid prototyping technology emerged in the hi-tech manufacture industry [112]. Since this technique can fabricate products with complex structure and individuation at a small batch, it can be realized in one design-manufacture process with high flexibility. Products with different shapes can be obtained by only modifying the computer-aided design (CAD) model using 3-D tomography data or magnetic resonance imaging (MRI) data, shortening the production cycle. The digital information is then converted to a machine specific cross-sectional format, expressing the model as a series of layers. The file is then implemented on the RP machine, which builds customer designed 3D objects by layered manufacturing strategy. Each layer represents the shape of the crosssection of the model at a specific level. Conventional manufacturing methods [111] are either difficult to employ or are unsuccessful in producing such porous devices with complex structure with the tight constraints of porosity, optimum pore size, or mechanical strength that are required. The drawbacks of the traditional methodologies for producing porous constructs include long fabrication periods, laborintensive processes, incomplete removal of residual chemicals or volatile porogenic elements, poor repeatability, irregularly shaped pores, insufficient interconnectivity of pores and thin wall structures, etc. RP techniques, also variously called solid free-form fabrication (SFF) or rapid manufacturing (RM), are considered a viable alternative for achieving extensive and detailed control over the scaffold architecture, shape and interconnectivity [113].

RP systems can also be utilized to produce a sacrificial mould to fabricate scaffolds. The multistep method involves casting of material in a mold and then removing or sacrificing the mold to obtain the final scaffold. Another important biological requirement is the surface properties of the fabricated scaffold. The topography of rapid prototyped surfaces can be further modified by sandblasting, shotpeening, vibratory deburring, spark anodization, electropolishing, acid etching, etc. Taking advantage of the possibilities of RP techniques load-bearing scaffolds with any predesigned structure and mechanical properties can be produced; so that they mimic the properties of the native bone and possess suitable strength for the intended application. Furthermore, CAD enables computational modeling and finite element analysis (FEA) prior to fabrication. Fluid flow analysis or stress distribution profiles can be obtained from computational models, thus allowing for re-design and scaffold optimization with minimal effort.

Until now RP developments mainly focused on polymer and ceramic materials [114]. However, recently several investigations have been carried out in order to produce 3-D porous metallic scaffolds using the RP route from 3-D solid models produced in CAD. For example, Li et al. [115] used a RP technology called 3D fiber deposition (3DF) for the fabrication of porous Ti-6Al-4V scaffolds with 
fully interconnected porous network and highly controllable porosity and pore size. Curodeau et al. [116] produced porous CoCr scaffolds manufactured by sacrificial wax template or investment casting. Murr et al. [117] reported the direct metal fabrication of non-stochastic titanium structures by electronbeam melting (EBM). Mullen et al. [118] produced porous titanium constructs by selective laser melting (SLM). This group also demonstrated that optimized structures can be produced with ideal qualities for bone ingrowth applications.

Table 5. Comparison of the different rapid prototyping (RP) technologies available for the fabrication of scaffolds aimed for hard tissue replacement.

\begin{tabular}{|c|c|c|c|c|}
\hline RP Technology & Material & Advantages & Disadvantages & Refs. \\
\hline $\begin{array}{l}\text { 3-dimensional } \\
\text { printing }^{\mathrm{TM}} \text { (3DP) }\end{array}$ & $\begin{array}{l}\text { Stainless steels, CoCr alloys, } \\
\text { Ti and its alloys. }\end{array}$ & $\begin{array}{l}\text { Microporosity induced in the scaffold; } \\
\text { enhanced range of materials can be used; fast } \\
\text { processing; Independent control of porosity } \\
\text { and pore size. }\end{array}$ & $\begin{array}{l}\text { Material must be in powder } \\
\text { form; powdery surface finish; } \\
\text { may required post-processing. }\end{array}$ & {$[116]$} \\
\hline $\begin{array}{l}\text { Sacrificial wax } \\
\text { template }\end{array}$ & Ta, Ti and its alloys. & $\begin{array}{l}\text { Less raw material required; the original } \\
\text { properties of the material are well conserved. }\end{array}$ & Multisteps involved. & {$[120,175,153]$} \\
\hline $\begin{array}{l}\text { 3D fiber deposition } \\
\text { technique (3DF) }\end{array}$ & $\mathrm{Ti}$ and its alloys. & $\begin{array}{l}\text { Preparation time is reduced; high surface } \\
\text { quality and high dimensional accuracy } \\
\text { shrinkage. }\end{array}$ & $\begin{array}{l}\text { Material must be in powder } \\
\text { form;low resolution. }\end{array}$ & {$[115]$} \\
\hline $\begin{array}{l}\text { Electron beam } \\
\text { melting (EBM) }\end{array}$ & Ti and its alloys. & Fast speed and less total time required. & $\begin{array}{l}\text { Costly; low surface quality } \\
\text { and low dimensional accuracy } \\
\text { shrinkage. }\end{array}$ & {$[117,121]$} \\
\hline $\begin{array}{l}\text { Selective laser } \\
\text { melting (SLM) }\end{array}$ & $\begin{array}{l}\text { Stainless steels, CoCr alloys, } \\
\text { Ti and its alloys, } \\
\text { intermetallics, refractory } \\
\text { metals, high temperature } \\
\text { alloys. }\end{array}$ & $\begin{array}{l}\text { Large variety of materials can be used in the } \\
\text { form of powder; does not use binders or } \\
\text { fluxing agents. }\end{array}$ & $\begin{array}{l}\text { Difficulty of removal of the } \\
\text { unbounded powder from the } \\
\text { porous internal architecture; } \\
\text { costly. }\end{array}$ & {$[118,119]$} \\
\hline $\begin{array}{l}\text { Direct metal } \\
\text { deposition (DMD) }\end{array}$ & $\mathrm{Ti}$ and its alloys. & $\begin{array}{l}\text { Deposit metals directly by layer deposition } \\
\text { without patterns; good geometry control and } \\
\text { surface finish. }\end{array}$ & $\begin{array}{l}\text { Material must be in powder } \\
\text { form; multisteps involved }\end{array}$ & {$[122]$} \\
\hline $\begin{array}{l}\text { Laser-engineered } \\
\text { net shaping } \\
\left(\mathrm{LENS}^{\mathrm{TM}}\right)\end{array}$ & $\begin{array}{l}\text { Stainless steels, CoCr alloys, } \\
\text { Ti and its alloys, } \\
\text { intermetallics, refractory } \\
\text { metals, high temperature } \\
\text { alloys. }\end{array}$ & $\begin{array}{l}\text { Reduce the lead time and investment cost for } \\
\text { modules and dies. }\end{array}$ & $\begin{array}{l}\text { Material must be in powder } \\
\text { form; costly. }\end{array}$ & {$[123,124]$} \\
\hline $\begin{array}{l}\text { Selective laser } \\
\text { sintering (SLS) }\end{array}$ & $\begin{array}{l}\text { Stainless steels, Ti and its } \\
\text { alloys. }\end{array}$ & $\begin{array}{l}\text { When mixed powders are used the powder of } \\
\text { low melting point act as a binder; very fine } \\
\text { resolution can be achieved; versatile in lay- } \\
\text { down interconnected porous design. }\end{array}$ & $\begin{array}{l}\text { Material must be in powder } \\
\text { form; powdery surface finish; } \\
\text { post-processing is required to } \\
\text { increase the final density and } \\
\text { mechanical properties. }\end{array}$ & {$[125,166]$} \\
\hline
\end{tabular}


Table 5 summarizes the key features of several RP techniques commonly used for the fabrication of porous metallic scaffolds. In general, the dimensional accuracy, mechanical properties, and applicable materials are restricted by each particular technology. Future development of porous constructs is mainly concerned with improving the RP techniques for creating specialized, low costs structures, which give long-term mechanical reliability to the engineered porous metal-bone interface.

\section{Biocompatibility of Commercially Available Metallic Scaffolds}

\subsection{Tantalum}

The efficacy of tissue-engineered tantalum constructs has been tested extensively in preclinical and clinical trials. Tables 6 and 7 show respectively the results of some preclinical and clinical trials using porous tantalum scaffolds.

Table 6. Preclinical studies using Ta scaffolds.

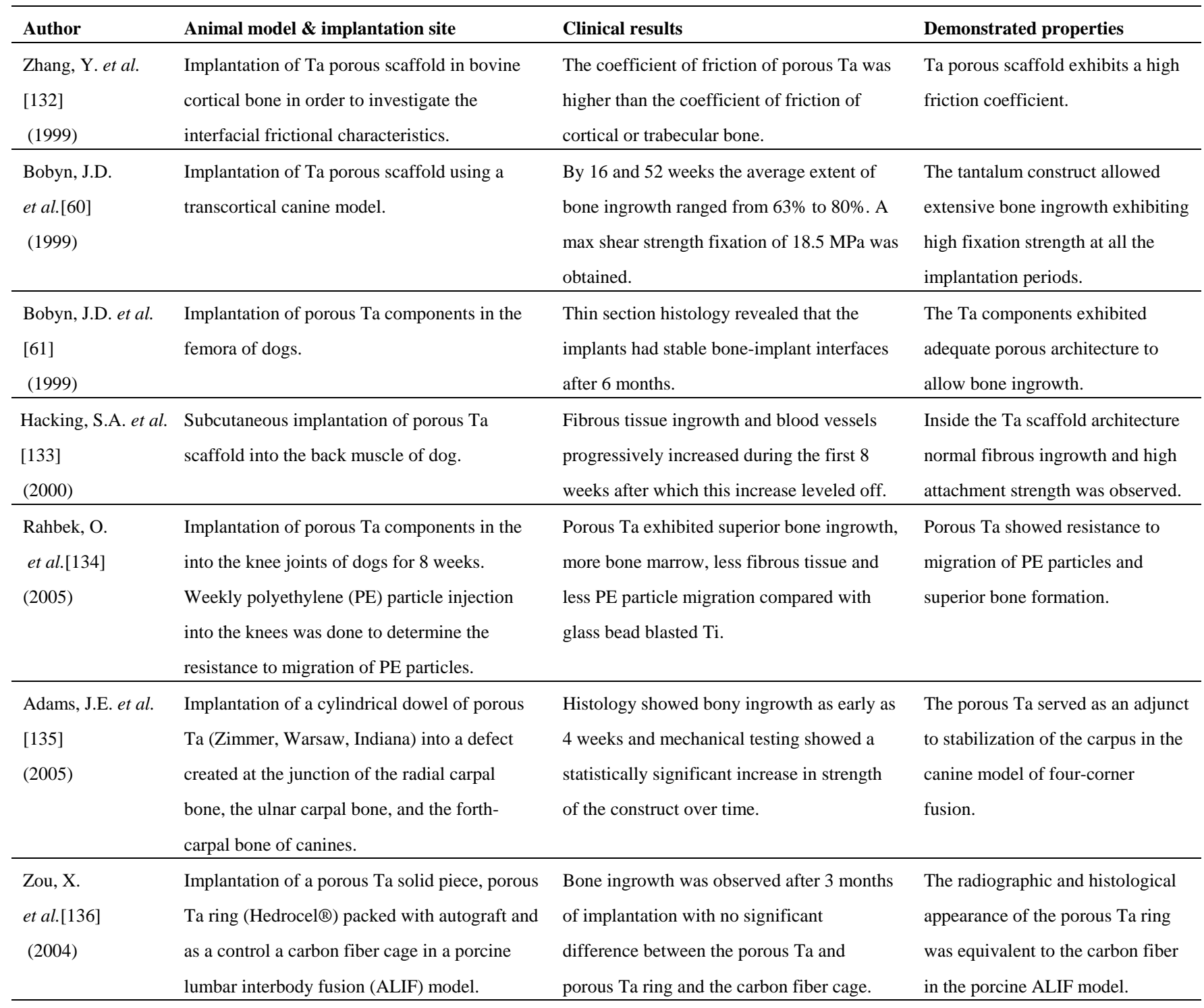


Table 6. Cont.

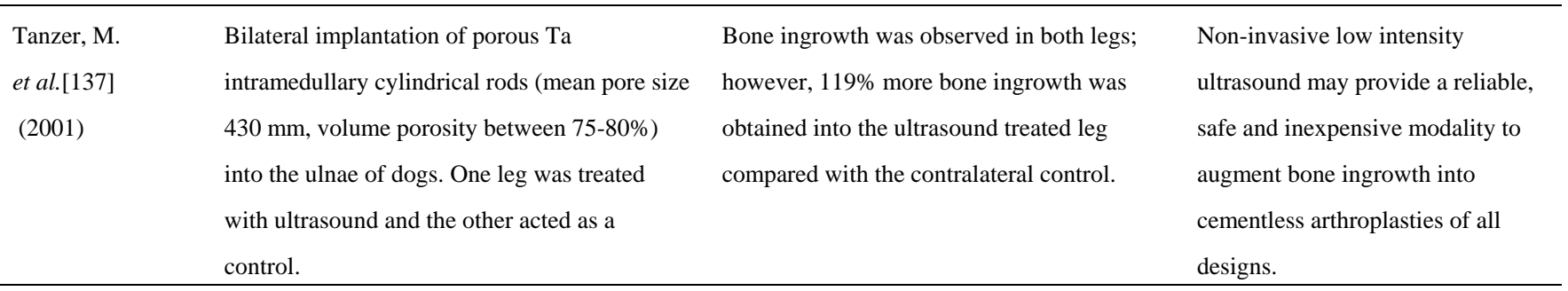

Table 7. Clinical studies using tantalum scaffolds.

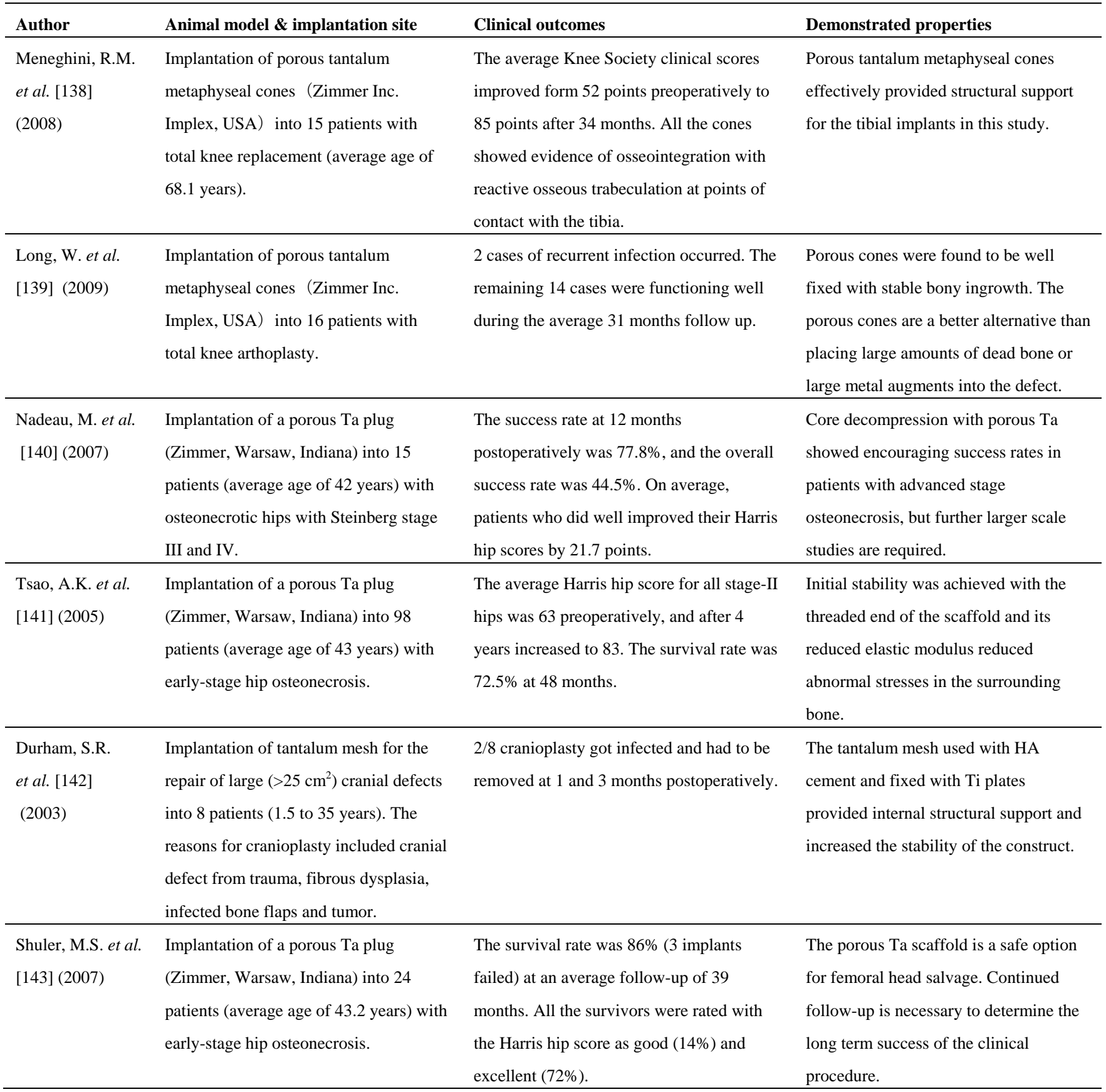

HA: Hydroxyapatite. 
Valuable preclinical results in laboratory animal experiments using commercially available tantalum constructs have led to the development of further applications of porous tantalum. For example, in total hip arthroplasty, spinal fusions, structural support of osteonecrosis and tumor related lesions, hand surgery lesions, maxillofacial surgery, etc. Data gained from these experiments have been invaluable leading to the advances of clinical trials in a controlled fashion. The majority of these short-term clinical studies exhibited promising favorable results, but long-term studies are needed. Nowadays, porous tantalum (Trabecular Metal ${ }^{\mathrm{TM}}$ ) in vivo testing is undergoing phase III and phase IV clinical trials.

\subsection{Magnesium}

Magnesium and magnesium alloys have similar mechanical properties with natural bone, but their high susceptibility to corrosion has limited their application in orthopedics. In the case of biodegradable scaffolds, it is desirable for the scaffold materials to be biodegraded completely after an appropriate period in a human body. An important method to slow down the degradation rate of magnesium is surface modification. Some surface modifications have been developed for porous $\mathrm{Mg}$ constructs to control the degradation rate as well as to improve the biocompatibility [126,127].

Table 8. Preclinical studies using magnesium scaffolds.

\begin{tabular}{|c|c|c|c|}
\hline Author & Animal model \& implantation site & Clinical results & Demonstrated properties \\
\hline $\begin{array}{l}\text { Reifenrath, J. } \\
\text { et al. [144] } \\
\text { (2005) }\end{array}$ & $\begin{array}{l}\text { Implantation of magnesium alloy AZ91 } \\
\text { open porous scaffolds (pore size distribution } \\
10-1000 \mu \mathrm{m} \text { and } 72-76 \% \text { porosity) into the } \\
\text { medial condyle of the knee of rabbits. }\end{array}$ & $\begin{array}{l}\text { Osteoconductive properties in the rim of } \\
\text { the scaffold were observed, however the } \\
\text { material did not induce the formation of } \\
\text { subchondral bone necessary for } \\
\text { osteochondral defect repair. }\end{array}$ & $\begin{array}{l}\text { AZ91 scaffold is a fast degrading } \\
\text { material that cannot sufficiently } \\
\text { replace the subchondral bone plate } \\
\text { during the first } 12 \text { weeks of } \\
\text { cartilage repair. }\end{array}$ \\
\hline $\begin{array}{l}\text { Witte, F. et al. } \\
\text { [145] (2006) }\end{array}$ & $\begin{array}{l}\text { Implantation of magnesium alloy AZ91 } \\
\text { open porous scaffolds (pore size distribution } \\
10-1000 \mu \mathrm{m} \text { and } 72-76 \% \text { porosity) into the } \\
\text { patellar cartilage of rabbits. }\end{array}$ & $\begin{array}{l}\text { New bone formation was observed at the } \\
\text { rim of the degrading scaffold. }\end{array}$ & $\begin{array}{l}\text { The surrounding cartilage tissue } \\
\text { was not negatively affected by the } \\
\text { rapid degradation process of the } \\
\text { scaffold. }\end{array}$ \\
\hline $\begin{array}{l}\text { Witte, F. et al. } \\
\text { [146] (2007) }\end{array}$ & $\begin{array}{l}\text { Implantation of magnesium alloy AZ91D } \\
\text { open porous scaffolds (pore size distribution } \\
10-1000 \mu \mathrm{m} \text { and } 72-76 \% \text { porosity) into the } \\
\text { distal femur condyle of rabbits to evaluate } \\
\text { the inflammatory response. }\end{array}$ & $\begin{array}{l}\text { After } 3 \text { months the scaffolds largely } \\
\text { degraded and most of the magnesium } \\
\text { alloy disappeared causing no harm to the } \\
\text { neighboring tissues }\end{array}$ & $\begin{array}{l}\text { Good biocompatibility with an } \\
\text { appropriate inflammatory host } \\
\text { response was observed. }\end{array}$ \\
\hline $\begin{array}{l}\text { Witte, F. et al. } \\
\text { [147] (2007) }\end{array}$ & $\begin{array}{l}\text { Implantation of magnesium alloy AZ91D } \\
\text { open porous scaffolds (pore size distribution } \\
10-1000 \mu \mathrm{m} \text { and } 72-76 \% \text { porosity) into the } \\
\text { condyles of the knee of rabbits to evaluate } \\
\text { the peri-implant bone remodeling. }\end{array}$ & $\begin{array}{l}\text { Higher BV/TV and more mature bone } \\
\text { structure were observed on the tissue } \\
\text { surrounding the magnesium scaffolds } \\
\text { compared with the control, which was } \\
\text { autologous bone. }\end{array}$ & $\begin{array}{l}\text { Fast degrading Mg scaffold } \\
\text { induced extended peri-implant } \\
\text { bone remodeling with a good } \\
\text { biocompatibility. }\end{array}$ \\
\hline
\end{tabular}

BV/TV: Bone volume per tissue volume.

Nowadays only in vitro [126,127] and preclinical studies using animal models have proposed the usage of Mg scaffolds as degradable scaffolds for bone substitute applications. Indeed, works dealing 
with the in vivo behavior of porous magnesium at the preclinical level are still very scarce. Table 8 lists the data derived from some preclinical studies using magnesium or magnesium alloys constructs.

\subsection{Titanium}

Porous titanium and titanium alloys have been shown to possess excellent mechanical properties as permanent orthopedic implants under load-bearing conditions [128]. Many basic scientific preclinical and clinical studies support the utility of $\mathrm{Ti}$ scaffolds. For marginal bone defects and bone augmentation $\mathrm{Ti}$ foams allow for bone ingrowth through interconnected porous [155]. On the other hand, titanium fiber-mesh is a useful scaffold material that warrants further investigation as a clinical tool for bone reconstructive surgery. In vitro, titanium fiber-mesh acts as a scaffold for the adhesion and the osteoblastic differentiation of progenitor cells [129]. In vivo, the material reveals itself to be osteoconductive, demonstrating encouraging results [182]. The studies described in Table 9, performed in clinically relevant large animal models, provide a wealth data demonstrating the safety and feasibility of the use of titanium scaffolds in the healing of bone defects.

Table 9. Preclinical studies using Ti scaffolds.

\begin{tabular}{|c|c|c|c|}
\hline Author & Animal model \& implantation site & Clinical results & Demonstrated properties \\
\hline $\begin{array}{l}\text { Matsuzaka, K. } \\
\text { et al.[148] } \\
(2005)\end{array}$ & $\begin{array}{l}\text { Implantation of Ti porous scaffold } \\
\text { fabricated by space holder technique } \\
\text { (pore size } 200-500 \mu \mathrm{m}, 78 \% \text { porosity) } \\
\text { with and without BMP-2 immobilization } \\
\text { in rat femur. }\end{array}$ & $\begin{array}{l}\text { Two weeks after implantation new bone } \\
\text { tissue formed around the scaffold with and } \\
\text { without BMP-2 immobilization. }\end{array}$ & $\begin{array}{l}\text { Ti porous scaffold with BMP-2 can } \\
\text { produce new bone tissue at an early } \\
\text { stage and can be beneficial in the repair } \\
\text { of bone defects. }\end{array}$ \\
\hline $\begin{array}{l}\text { Ponader, S. } \\
\text { et al.[149] } \\
\text { (2009) }\end{array}$ & $\begin{array}{l}\text { Implantation of porous Ti6Al4V scaffold } \\
\text { fabricated by selective electron beam } \\
\text { melting (SEBM) (pore size } 450 \mu \mathrm{m} \text {, } \\
61.3 \% \text { porosity) into defects in the frontal } \\
\text { skull of domestic pigs. }\end{array}$ & $\begin{array}{l}\text { Bone ingrowth }(\approx 46 \%) \text { was reached after } \\
60 \text { days and the healing bone structure in } \\
\text { the outer region of the scaffold was } \\
\text { comparable with that of pristine bone. }\end{array}$ & $\begin{array}{l}\text { The scaffold shows adequate } \\
\text { architecture to allow bone ingrowth and } \\
\text { excellent mechanical properties. }\end{array}$ \\
\hline $\begin{array}{l}\text { Li, J.P. et al. } \\
{[150](2007)}\end{array}$ & $\begin{array}{l}\text { Implantation of porous Ti6Al4V scaffold } \\
\text { made by 3D fiber (3DF) deposition (pore } \\
\text { size } 160-680 \mu \mathrm{m}, 39-68 \% \text { porosity) into } \\
\text { the posterior lumbar spine of goats. }\end{array}$ & $\begin{array}{l}\text { Bone ingrowth progressively increased } \\
\text { during the first nine weeks after which this } \\
\text { increase leveled off. }\end{array}$ & $\begin{array}{l}\text { Scaffold architecture can be easily } \\
\text { controlled and changes in the porosity } \\
\text { and pore size had a positive effect on } \\
\text { the amount of new bone formation. }\end{array}$ \\
\hline $\begin{array}{l}\text { Bottino, M.C. } \\
\text { et al. }[151] \\
(2009)\end{array}$ & $\begin{array}{l}\text { Implantation of powder metallurgy (P/M) } \\
\text { processed Ti13Nb13Zr porous samples } \\
\text { (pore size } 50-100 \mu \mathrm{m}, 30 \% \text { porosity) into } \\
\text { rabbit tibiae for } 8 \text { weeks. }\end{array}$ & $\begin{array}{l}\text { Close bone-implant contact observed, } \\
\text { however due to the absence of open as well } \\
\text { as interconnected pores no bone ingrowth } \\
\text { was observed. }\end{array}$ & $\begin{array}{l}\text { Porous Ti13Nb13Zr manufactured by } \\
\text { P/M with metallic hydrides were non- } \\
\text { cytotoxic but pore structure and pore } \\
\text { distribution were non appropriate for } \\
\text { bone ingrowth. }\end{array}$ \\
\hline $\begin{array}{l}\text { Chang, Y.-S. } \\
\text { et al.[152] } \\
\text { (1998) }\end{array}$ & $\begin{array}{l}\text { Implantation of fiber meshes fabricated } \\
\text { by sintering and plasma spraying (pore } \\
\text { size } 200-400 \mu \mathrm{m}, 56-60 \% \text { porosity) into } \\
\text { femoral defects in dogs. }\end{array}$ & $\begin{array}{l}\text { Abundant bone ingrowth was observed that } \\
\text { resulted in the complete integration of this } \\
\text { composite device implant and the host } \\
\text { bone. }\end{array}$ & $\begin{array}{l}\text { Scaffolds with 3-D open pore structure } \\
\text { led to complete osseointegration. }\end{array}$ \\
\hline
\end{tabular}


Table 9. Cont.

\begin{tabular}{|c|c|c|c|}
\hline $\begin{array}{l}\text { Lopez-Heredia, } \\
\text { M.A. et al. } \\
\text { [153] (2008) }\end{array}$ & $\begin{array}{l}\text { Implantation of scaffold made by rapid } \\
\text { prototyping (RP) technique (pore size } 800 \\
\text { and } 1200 \mu \mathrm{m}, 60 \% \text { porosity) into the } \\
\text { femoral epiphysis of rabbits. }\end{array}$ & $\begin{array}{l}\text { Bone ingrowth observed }(\approx 24 \%) \text { after } 3 \\
\text { weeks with no difference between the two } \\
\text { pore sizes. BIC were around } 30 \% \text {. }\end{array}$ & $\begin{array}{l}\text { RP Ti scaffolds possess excellent } \\
\text { mechanical and biological properties. }\end{array}$ \\
\hline $\begin{array}{l}\text { Takemoto, M. } \\
\text { et al.[154] } \\
\text { (2007) }\end{array}$ & $\begin{array}{l}\text { Implantation of porous Ti with a } \\
\text { bioactive titania layer fabricated by the } \\
\text { spacer method (mean pore size } 303 \mu \mathrm{m} \text {, } \\
50 \% \text { porosity) into the anterior lumbar } \\
\text { spine in dogs. }\end{array}$ & $\begin{array}{l}\text { Interbody fusion was confirmed in all five } \\
\text { dogs. Histological evaluation demonstrated } \\
\text { a large amount of new bone formation with } \\
\text { marrow like tissue into the bioactive } \\
\text { scaffolds. }\end{array}$ & $\begin{array}{l}\text { Bioactive alkali and heat-treatment } \\
\text { effectively enhanced the bone-bonding } \\
\text { and the fusion ability of the porous Ti } \\
\text { scaffolds. }\end{array}$ \\
\hline $\begin{array}{l}\text { Pinto-Faria, } \\
\text { P.E. et al. } \\
\text { [155] (2008) }\end{array}$ & $\begin{array}{l}\text { Implantation of porous Ti sponge rods } \\
\text { made by space holder method (pore size } \\
200 \sim 500 \mu \mathrm{m}, 80 \% \text { porosity) for the } \\
\text { healing of humerus bone defects in a } \\
\text { canine model. As a control HA granules } \\
\text { were used. }\end{array}$ & $\begin{array}{l}\text { HA granules rendered more bone formation } \\
\text { than the Ti foam after } 2 \text { and } 4 \text { moths of } \\
\text { implantation. However the Ti foam led to a } \\
\text { better bone-growth distribution in the } \\
\text { implanted sites. }\end{array}$ & $\begin{array}{l}\text { The Ti foam exhibited good } \\
\text { biocompatibility, and its application } \\
\text { resulted in improved maintenance of the } \\
\text { bone height compared with control sites } \\
\text { filled with HA granules. }\end{array}$ \\
\hline $\begin{array}{l}\text { Walboomers, } \\
\text { X.F. et al. } \\
\text { [156] (2005) }\end{array}$ & $\begin{array}{l}\text { Implantation of hollow cylindrical fiber } \\
\text { mesh scaffold filled and unfilled with } \\
\text { COLLOSS } ® \text { into the back of rats. }\end{array}$ & $\begin{array}{l}\text { After } 12 \text { weeks of implantation in the } \\
\text { control scaffold no bone-like tissue } \\
\text { formation was evident in almost all } \\
\text { samples. }\end{array}$ & $\begin{array}{l}\text { The COLLOSS }{ }^{\circledR} \text { filled scaffold showed } \\
\text { bone-inducing properties. Bone marrow } \\
\text { tissue formation was evident in almost } \\
\text { all samples. }\end{array}$ \\
\hline
\end{tabular}

RBM: Rat bone marrow; BIC: Bone-implant contact; HA: Hydroxyapatite; COLLOSS®: Bovine extracellular matrix product containing native BMPs.

Table 10. Clinical studies using titanium scaffolds.

\begin{tabular}{|c|c|c|c|}
\hline Author & Animal model \& implantation site & Clinical outcomes & Demonstrated properties \\
\hline $\begin{array}{l}\text { van Jonbergen, } \\
\text { H-P.W. et al. } \\
\text { [157] (2005) }\end{array}$ & $\begin{array}{l}\text { Implantation of titanium SynCage C (Synthes, } \\
\text { Oberdorf, Switzerland) filled with autogenous } \\
\text { bone graft into } 71 \text { patients ( } 23 \text { to } 76 \text { years) } \\
\text { with cervical disc disease and cervical spinal } \\
\text { stenosis. }\end{array}$ & $\begin{array}{l}\text { Fusion was achieved after } 6 \text { months } \\
\text { in all patients; however, } 10 \text { cages } \\
\text { (each in a different patient) had } \\
\text { subsided. }\end{array}$ & $\begin{array}{l}\text { Subsidence behavior of this titanium } \\
\text { cage deign was noted and is a disturbing } \\
\text { phenomenon. A modified cage design } \\
\text { with improved and extended lower } \\
\text { contact surface could be expected to } \\
\text { reduce subsidence. }\end{array}$ \\
\hline $\begin{array}{l}\text { Eck, K.R. et al. } \\
\text { [158] (2000) }\end{array}$ & $\begin{array}{l}\text { Implantation of titanium mesh cages into } 66 \\
\text { consecutive adult patients (ages 20-81 years) } \\
\text { with sagittal deformities. The cages were } \\
\text { inserted into the anterior column during } \\
\text { posterior instrumentation and fusion. }\end{array}$ & $\begin{array}{l}\text { No cage failure or extrusion was } \\
\text { observed. The average segmental } \\
\text { improvement in lordosis with cage } \\
\text { implantation was } 11^{\circ} \text { with a loss of } \\
\text { correction of less than } 1^{\circ} \text { after } 2 \\
\text { years. }\end{array}$ & $\begin{array}{l}\text { Structural titanium mesh cages } \\
\text { implanted into the anterior column } \\
\text { functioned appropriately to maintain } \\
\text { sagittal correction and with rare } \\
\text { radiographic complications were } \\
\text { obtained. }\end{array}$ \\
\hline $\begin{array}{l}\text { Kuttenberger, } \\
\text { J.J. et al. [159] } \\
\text { (2001) }\end{array}$ & $\begin{array}{l}\text { Implantation of laser-perforated titanium } \\
\text { micro-mesh (Howmedica Leibinger GmbH \& } \\
\text { Co., Germany) into } 20 \text { patients (ages 22-78 } \\
\text { years) with defects in the craniofacial and/or } \\
\text { orbito-ethmoidal region. }\end{array}$ & $\begin{array}{l}\text { No wound infections, exposures or } \\
\text { loss of the mesh have been observed. } \\
\text { Long-term stability reconstruction } \\
\text { was excellent ( } 8 \text { years follow-up). }\end{array}$ & $\begin{array}{l}\text { Radiographs and CT scans demonstrated } \\
\text { that stable 3-D reconstructions of } \\
\text { complex anatomical structures were } \\
\text { achieved in all the treated patients. }\end{array}$ \\
\hline
\end{tabular}


Table 10. Cont.

\begin{tabular}{|c|c|c|c|}
\hline $\begin{array}{l}\text { Bystedt, H. } \\
\text { et al. [160] }\end{array}$ & $\begin{array}{l}\text { Implantation of porous titanium granules } \\
\text { (Natix }^{\mathrm{TM}} \text {, Tigran Tech. AB, Sweden) into } 16\end{array}$ & $\begin{array}{l}1 \text { patient had postoperative sinus } \\
\text { infection. The postoperative }\end{array}$ & $\begin{array}{l}\text { Titanium granules seem to function well } \\
\text { as augmentation material in the sinus }\end{array}$ \\
\hline (2008) & $\begin{array}{l}\text { consecutive patients ( } 55 \text { to } 83 \text { years) with the } \\
\text { need of augmentation of the sinus floor. }\end{array}$ & $\begin{array}{l}\text { radiographs showed no signs of } \\
\text { migration of the granules. }\end{array}$ & $\begin{array}{l}\text { floor. Biopsies to confirm bone ingrowth } \\
\text { are needed. }\end{array}$ \\
\hline $\begin{array}{l}\text { Jaquiéry, C. } \\
\text { et al. [161] } \\
\text { (2007) }\end{array}$ & $\begin{array}{l}\text { Implantation of titanium meshes some of them } \\
\text { filled with autogenous bone graft into } 26 \\
\text { patients (13 to } 82 \text { years) with small and mid- } \\
\text { size orbital defects (categories I, II, and III). }\end{array}$ & $\begin{array}{l}\text { Postoperatively, } 91 \% \text { of the patients } \\
\text { had normal vision and accuracy of } \\
\text { reconstruction was achieved in } \\
\text { category II defects. }\end{array}$ & $\begin{array}{l}\text { Titanium meshes provided stability and } \\
\text { can support the orbital content } \\
\text { preventing the risk of a secondary } \\
\text { enophthalmos. }\end{array}$ \\
\hline $\begin{array}{l}\text { Scholz, M. } \\
\text { et al. [162] } \\
\text { (2007) }\end{array}$ & $\begin{array}{l}\text { Implantation of individually prefabricated } \\
\text { CAD/CAM titanium porous plate into } 1 \text { male } \\
\text { patient (16-year-old) with a severe head injury } \\
\text { including an intracranial hematoma. }\end{array}$ & $\begin{array}{l}\text { CAD/CAM titanium porous plate } \\
\text { served as a virtual template for a } \\
\text { precise surgical resection along a pre- } \\
\text { established geometry ensuring the } \\
\text { perfect fit of the scaffold. }\end{array}$ & $\begin{array}{l}\text { CAD/CAM titanium porous plate are } \\
\text { suitable for reconstructing large bone } \\
\text { defects in the skull because provide } \\
\text { long-term stability, quick installation } \\
\text { and very good cosmetic results. As a } \\
\text { disadvantage, CAD/CAM technology is } \\
\text { more expensive than a titanium mesh, } \\
\text { and the process is time-consuming as it } \\
\text { is carried out in advance of surgery. }\end{array}$ \\
\hline
\end{tabular}

CAD/CAM: Computer-aided design/computer-aided manufacturing.

Results of these preclinical studies confirm that healing of bone is possible using biochemicallymodified Ti scaffolds, specifically by the use of growth factors and osteoprogenitor cells. However, the assessment of the potential for the use of these biochemically-modified Ti scaffolds for clinical applications in the future lies on the capability of the researches to show excellent long-term results. Clinically, cylindrical titanium meshes have been used with consistently good results for large anterior column defect reconstructions. Implantation of synthetic cages into the anterior column seems to offer immediately effective segmental stability, correction of the sagittal plane deformity, and restoration of the anterior vertebral support from a biomechanical standpoint. These anterior interbody cages provide a satisfactory axial load-bearing capacity, and morcellized autograft can be used to fill the inside of the cage [158]. Table 10 lists the results of some clinical studies that employed porous Ti scaffolds for hard tissue repairing and reconstruction. Although there is a paucity of literature regarding the clinical outcomes and result of porous titanium scaffolds, longer follow-up periods and a larger sample group of patients are required in order to obtain reliable clinical success rates.

\subsection{Nickel-Titanium Alloy (Nitinol)}

Porous Nitinol (PNT) has been used in maxillofacial and some orthopaedic surgeries in Russia and China for approximately 15 years [130]. PNT has aroused interest also in intervertebral disc pathologies as an interbody fusion bone scaffold [131]. However, until now few preclinical trials using animal models and very scarce clinical trials have been carried out and more research may be required to better understand the biological performance of PNT. Table 11 shows some preclinical studies carried out with porous Nitinol as scaffold material. The majority of the clinical studies using Nitinol 
meshes are limited to the thoracic and cardiovascular surgery field where Nitinol finds application especially in self-expanded metallic stents.

Table 11. Preclinical studies using NiTi scaffolds.

\begin{tabular}{|c|c|c|c|}
\hline Author & Animal model \& implantation site & Clinical results & Demonstrated properties \\
\hline $\begin{array}{l}\text { Ayers, R.A. et al. } \\
\text { [163] (1999) }\end{array}$ & $\begin{array}{l}\text { Implantation of NiTi porous scaffold } \\
\text { fabricated by SHS (pore sizes 353, } 218 \text { and } \\
179 \mu \mathrm{m} \text {, porosity 43, } 54 \text { and 51\%) into } \\
\text { cranial defects in rabbits. }\end{array}$ & $\begin{array}{l}\text { Bone ingrowth observed in the three types } \\
\text { of implants. }\end{array}$ & $\begin{array}{l}\text { The used pore sizes appear not to affect } \\
\text { bone ingrowth during the cartilaginous } \\
\text { period of bone ingrowth. }\end{array}$ \\
\hline $\begin{array}{l}\text { Kujala, S. et al. } \\
\text { [164] (2003) }\end{array}$ & $\begin{array}{l}\text { Implantation of NiTi porous scaffold } \\
\text { fabricated by SHS (pore sizes } 259 \text { and } 505 \\
\mu \mathrm{m} \text {, porosity } 66 \text { and } 47 \% \text { ) into femoral } \\
\text { defects in rats. }\end{array}$ & $\begin{array}{l}\text { Bone ingrowth observed, porosity of } 66 \% \\
\text { showed the best bone-implant contact. }\end{array}$ & $\begin{array}{l}\text { The scaffold allows bone ingrowth, } \\
\text { although fibrosis inside the porous } \\
\text { structure was observed in some cases. }\end{array}$ \\
\hline $\begin{array}{l}\text { Simske, S.J. et al. } \\
\text { [165] (1995) }\end{array}$ & $\begin{array}{l}\text { Implantation of porous NiTi scaffold made } \\
\text { by SHS (pore size } \approx 300 \mu \mathrm{m}, \approx 50 \% \\
\text { porosity) into cranial defects in rabbits. }\end{array}$ & $\begin{array}{l}\text { Bone contact with the surrounding cranial } \\
\text { tissue and bone ingrowth observed. }\end{array}$ & $\begin{array}{l}\text { Porous NiTi exhibited more total bone } \\
\text { ingrowth than coralline HA after } 12 \\
\text { weeks of implantation. }\end{array}$ \\
\hline $\begin{array}{l}\text { Shishkovsky, I.V. } \\
\text { et al. }[166] \\
\text { (2008) }\end{array}$ & $\begin{array}{l}\text { Implantation of porous NiTi scaffold made } \\
\text { by SLS and SHS (nanostructured walls in } \\
\text { the range of } 1460-460 \mathrm{~nm} \text { ) into dextral } \\
\text { blade bone of rats. }\end{array}$ & $\begin{array}{l}\text { No adverse tissue reactions were observed } \\
\text { and the histological samples showed no } \\
\text { evidence of bone resorption in the cranial } \\
\text { bone adjacent to the scaffolds. }\end{array}$ & $\begin{array}{l}\text { The porosity and the surface chemistry } \\
\text { engineered in the combined SLS-SHS } \\
\text { process were suitable for biointegration. }\end{array}$ \\
\hline $\begin{array}{l}\text { Zhu, S.L. et al. } \\
\text { [167] (2008) }\end{array}$ & $\begin{array}{l}\text { Implantation of porous NiTi scaffold } \\
\text { prepared by element powder sintering } \\
\text { (mean pore size } 130 \mu \mathrm{m}, 45 \% \text { porosity) } \\
\text { into the long axis of the femur of rabbits. }\end{array}$ & $\begin{array}{l}\text { Histological sections showed that the } \\
\text { osteoblasts were directly in contact with } \\
\text { the porous NiTi without intervenient } \\
\text { fibrous tissue. Bone ingrowth was also } \\
\text { observed in the inner of the scaffold. }\end{array}$ & $\begin{array}{l}\text { Good bone-implant contact was obtained } \\
\text { in the porous NiTi. Porous NiTi alloy } \\
\text { exhibited better osteoconductivity and } \\
\text { osseointegration than bulk one. }\end{array}$ \\
\hline $\begin{array}{l}\text { Rhalmi, S. et al. } \\
\text { [168] (1999) }\end{array}$ & $\begin{array}{l}\text { Implantation of porous NiTi blocks }(5 \times 3 \\
\times 3 \mathrm{~mm} \text { volume, pore size range } 400 \mu \mathrm{m}< \\
\varnothing<900 \mu \mathrm{m}) \text { into the tibias and back } \\
\text { muscle of rabbits. }\end{array}$ & $\begin{array}{l}\text { Muscle tissue exhibited thin tightly } \\
\text { adherent fibrous capsules with fibers } \\
\text { penetrating into implant pores. Bone } \\
\text { tissue demonstrated good healing of the } \\
\text { osteotomy. There was bone remodeling } \\
\text { characterized by osteoclastic and } \\
\text { osteoblastic activity in the cortex. }\end{array}$ & $\begin{array}{l}\text { Good biocompatibility acceptance of } \\
\text { porous NiTi was observed in both } \\
\text { muscle and bone tissue. The results } \\
\text { corresponded very well with the in vitro } \\
\text { cell culture evaluation. }\end{array}$ \\
\hline $\begin{array}{l}\text { Rhalmi, S. et al. } \\
\text { [169] (2007) }\end{array}$ & $\begin{array}{l}\text { Implantation of porous NiTi IFD } \\
\text { manufactured by Biorthex Inc., Canada. } \\
\text { (pore size } 230 \pm 130 \mu \mathrm{m}, 65 \pm 10 \% \\
\text { porosity) into the spinal canal of the dura } \\
\text { mater at the lumbar level L2-L3 in rabbits. }\end{array}$ & $\begin{array}{l}\text { In contact with the dura mater NiTi elicits } \\
\text { an inflammatory response similar to that } \\
\text { of Ti. The inflammation was limited to the } \\
\text { spidural space and then reduced from } \\
\text { acute to mild chronic after } 1 \text { year. }\end{array}$ & $\begin{array}{l}\text { The tolerance of NiTi by a sensitive } \\
\text { tissue such as the dura mater during the } \\
\text { span of } 1 \text { year of implantation } \\
\text { demonstrated the safety of NiTi and its } \\
\text { potential use as an IFD. }\end{array}$ \\
\hline $\begin{array}{l}\text { Wu, S. et al. } \\
{[170](2008)}\end{array}$ & $\begin{array}{l}\text { Implantation of a hydrothermally treated } \\
\text { 3D porous NiTi scaffolds fabricated by CF- } \\
\text { HIP into the femurs of rabbits. Hierarchical } \\
\text { porous nanostructures external layer of } \\
\text { bioactive titanate was obtained. }\end{array}$ & $\begin{array}{l}\text { Bone tissue could grow smoothly into the } \\
\text { internal pores of the scaffolds and made } \\
\text { good contact with the exposed surface of } \\
\text { the scaffold. }\end{array}$ & $\begin{array}{l}\text { The external nanostructure obtained } \\
\text { facilitates the biomineralization and } \\
\text { promote deposition of bone-like apatite } \\
\text { and proliferation of osteoblasts. }\end{array}$ \\
\hline
\end{tabular}

SHS: Self-propagating high-temperature synthesis; SLS: Selective laser sintering; IFD: Interbody fusion device; CF-HIP: Capsule freehot isostatic pressing method. 
Table 12 shows the results of two specific clinical trials using porous Nitinol. The first trial employed a porous Nitinol superelastic expandable cage that can be twisted into any shape and return to the original shape when the compression force is lifted [171]. The second trial corresponds to the midface endoprosthetic area. PNT constructs were used in the midface reconstruction in 129 patients with encouraging results [172]. However, continued follow-up is necessary to determine the clinical long-term success of these PNT constructs.

Table 12. Clinical studies using NiTi scaffolds.

\begin{tabular}{|c|c|c|c|}
\hline Author & Animal model \& implantation site & Clinical outcomes & Demonstrated properties \\
\hline $\begin{array}{l}\text { Wang, Y. et al. } \\
\text { [171] (2008) }\end{array}$ & $\begin{array}{l}\text { Implantation of NiTi porous superelastic cage } \\
\text { in } 62 \text { patients ( } 21 \text { to } 61 \text { years) with total hip } \\
\text { arthroplasty (THA). }\end{array}$ & $\begin{array}{l}\text { The total survival rate was } 82.7 \% \text { (67/81 } \\
\text { hips) without further treatment. Of } 81 \\
\text { hips, } 14 \text { (17.3\%) had progressive pain } \\
\text { with collapsed femoral head resulting in } \\
\text { THA. }\end{array}$ & $\begin{array}{l}\text { The superelastic cage provided } \\
\text { structural support to the subchondral } \\
\text { bone in the necrotic femoral head, } \\
\text { also decreased the further collapsing } \\
\text { trend of the ONFH and helped to } \\
\text { regain contour of articular surface of } \\
\text { the collapsed femoral head. }\end{array}$ \\
\hline $\begin{array}{l}\text { Arsenova, I.A. } \\
\text { et al. [172] } \\
(2005)\end{array}$ & $\begin{array}{l}\text { Implantation of porous NiTi scaffold } \\
\text { saturated with bone marrow into midface } \\
\text { bony defects into } 129 \text { patients ( } 74 \\
\text { endoprosthetics of inferior wall of the orbit, } \\
26 \text { endoprosthetics of maxillary walls, } 14 \\
\text { maxillary endoprosthetics, } 12 \\
\text { endoprosthetics of supporting structures of } \\
\text { the nose, } 3 \text { zygomoorbital region). }\end{array}$ & $\begin{array}{l}\text { The study of grinds done after } 180 \text { days } \\
\text { of implantation revealed that most part of } \\
\text { the pores were filled with bone tissue, the } \\
\text { quantity of calcium in the pores was } \\
\text { similar to one in bone tissue. Positive } \\
\text { results of endoprosthetics were achieved } \\
\text { in } 123 \text { patients. }\end{array}$ & $\begin{array}{l}\text { PNT structures possess good } \\
\text { integration with tissue structures and } \\
\text { need further study of possibilities of } \\
\text { their use in reconstructive surgery of } \\
\text { facial skull and temporomandibular } \\
\text { joint (TMJ). }\end{array}$ \\
\hline
\end{tabular}

ONFH: Osteonecrosis of the femoral head; PNT: Porous Nitinol.

\subsection{Hybrid Constructs}

Upon the placement of a scaffold into a surgical site, there is a cascade of molecular and cellular processes that provides for new bone growth and differentiation along the biomaterial surface. The goal of a number of current strategies is to provide an enhanced osseous stability through microsurface mediated events. These strategies can be divided into those that attempt to enhance the immigration of new bone (e.g., osteoconduction) through changes in surface topography (e.g., surface roughness, porous surface, etc.), biological means to manipulate the type of cells that grow onto the surface and strategies to utilize the scaffold as a vehicle for local delivery of a bioactive coating (adhesion matrix or growth factor such as BMPs) that may achieve osteoinduction of new bone differentiation within the scaffold surface. Calcium phosphate (Ca-P) ceramics have been successfully proposed as bone substitutes because of their chemical similarities with bone mineral. Hybrid constructs of $\mathrm{Ti}$ or $\mathrm{Ta} /$ osteogenic cells, $\mathrm{Ti}$ or $\mathrm{Ta} / \mathrm{Ca}-\mathrm{P}$ ceramics, and $\mathrm{Ti}$ or Ta/growth factors have demonstrated very good osteogenic properties compared with non-modified Ti or non-modified Ta, suggesting that the surface modification of $\mathrm{Ti}$ and $\mathrm{Ta}$ plays an important role in bone tissue engineering. In the case of Ca-P coated scaffolds physicochemical and crystallographic continuity have been observed in vivo between the calcium phosphate coated external surface and the newly 
mineralized layer [179]. This mineralized interface ensures a physicochemical and mechanical cohesion between the scaffold and the host bone. Tables 13 and 14 show some preclinical trials made in different animal models using hybrid $\mathrm{Ti}$ and $\mathrm{Ta}$ constructs, respectively. In the field of tissue engineering, the grafting of arginine-glycine-aspartic acid (RGD) peptides has been the focus of much attention [176,181,185]. Their presence at biomaterials surfaces improved cell adhesion. Indeed, this peptide sequence is present in various extracellular matrix and plasma proteins, and it constitutes a major recognition site of a large number of adhesive extracellular matrix, blood and cell surface proteins [185]. The immobilization of bioactive molecules such as BMP-2 into the metallic biomaterial surface leads to the differentiation of the cells towards osteogenic lineage improving the osseointegration [174]. Based upon the promising results obtained from the preclinical studies, carefully selected and controlled clinical trials with rhBMP-2 have begun [201]. Ti scaffolds have also found application as delivery systems for transforming growth factors $\beta-1$ (TGF- $\beta 1$ ) [183]. On the other hand, adjusting the underlying micro-and nanotopography is also a smart way to trigger and modulate specific cellular functions. This approach was attempted by Wu et al. [170] using porous NiTi, and Takemoto et al. [154] using porous Ti. The combined effect of topography and biochemical cues using bone-stimulating agents is indeed an interesting path to improve the biocompatibility.

Table 13. Preclinical studies using titanium-ceramic, titanium-polymer, or cell loaded titanium scaffolds.

\begin{tabular}{|c|c|c|c|}
\hline Author & Animal model \& implantation site & Clinical results & Demonstrated properties \\
\hline $\begin{array}{l}\text { Zhang, E. et al. } \\
{[173](2009)}\end{array}$ & $\begin{array}{l}\text { Implantation of Si-HA coated-porous Ti } \\
\text { fabricated by fiber sintering (pore sizes 150- } \\
600 \mu \mathrm{m} \text {, porosity 67\%) into the femora of } \\
\text { rabbits. }\end{array}$ & $\begin{array}{l}\text { High bone ingrowth rate was observed } \\
\text { inside the } 3 \mathrm{D} \text { interconnected pore } \\
\text { structure. }\end{array}$ & $\begin{array}{l}\text { Si-HA coating significantly improved } \\
\text { the surface bioactivity of the porous } \\
\text { Ti. The existent Si ions might have } \\
\text { been the cause of the improved } \\
\text { bioactivity obtained. }\end{array}$ \\
\hline $\begin{array}{l}\text { Peng, L. et al. } \\
\text { [174] (2008) }\end{array}$ & $\begin{array}{l}\text { Implantation of HA coated-porous scaffold } \\
\text { fabricated by sintering premodified by alkali } \\
\text { and heat treatment with BMP-2 and } \\
\text { hylauronic acid into the femora of rabbits. }\end{array}$ & $\begin{array}{l}\text { Bone ingrowth observed. HA-coated } \mathrm{Ti} \\
\text { scaffolds achieved lower osseointegration } \\
\text { than the BMP-2 group. }\end{array}$ & $\begin{array}{l}\text { HA-coated Ti scaffolds with BMP-2 } \\
\text { and hyluronic acid had a good effect } \\
\text { in repairing bone defects. }\end{array}$ \\
\hline $\begin{array}{l}\text { Lopez-Heredia, } \\
\text { M.A. et al. } \\
\text { [175] (2008) }\end{array}$ & $\begin{array}{l}\text { Implantation of CaP-coated Ti scaffold } \\
\text { made by rapid prototyping technique (pore } \\
\text { size } 1000 \mu \mathrm{m}, 50 \% \text { porosity) into the dorsal } \\
\text { subcutaneous pounches of rats. }\end{array}$ & $\begin{array}{l}\text { After } 4 \text { weeks of subcutaneous } \\
\text { implantation mineralized collagen was } \\
\text { observed but not mature bone. }\end{array}$ & $\begin{array}{l}\text { Scaffold architecture could be easily } \\
\text { coated with CaP and according to the } \\
\text { in vitro evaluation with RBMC cells } \\
\text { the biocompatibility was improved by } \\
\text { the coating applied. }\end{array}$ \\
\hline $\begin{array}{l}\text { Sargeant, T.D. } \\
\text { et al.[176] } \\
\text { (2008) }\end{array}$ & $\begin{array}{l}\text { Implantation of a Ti6Al4V foam made by } \\
\text { HIPing (pore size } 165 \mu \mathrm{m} \text {, porosity } 52 \% \text { ), } \\
\text { whose porosity was filled with a peptide } \\
\text { amphiphile (PA) nanofiber matrix into a rat } \\
\text { femoral defect. }\end{array}$ & $\begin{array}{l}\text { PA-Ti hybrid constructs exhibited bone } \\
\text { ingrowth and the newly formed bone } \\
\text { around and inside the implant were highly } \\
\text { mineralized after } 4 \text { weeks of implantation. }\end{array}$ & $\begin{array}{l}\text { By filling the porosity of the scaffold } \\
\text { with PA bone mineralization was } \\
\text { successfully induced. }\end{array}$ \\
\hline $\begin{array}{l}\text { Sikavitsas, V.I. } \\
\text { et al. [177] } \\
\text { (2003) }\end{array}$ & $\begin{array}{l}\text { Implantation of bone marrow stromal } \\
\text { osteoblasts-loaded Ti fiber mesh composite } \\
\text { scaffold (fiber } \varnothing 45 \mu \mathrm{m} \text {, porosity > 86\%) } \\
\text { into calvarial defects in rats. }\end{array}$ & $\begin{array}{l}\text { Bone ingrowth observed. The highest \% } \\
\text { of bone formation was obtained in the } \\
\text { cell-loaded scaffolds (64\%). }\end{array}$ & $\begin{array}{l}\text { Osteoinductivity and high bone } \\
\text { regeneration was achieved thanks to } \\
\text { the cells loading. }\end{array}$ \\
\hline
\end{tabular}


Table 13. Cont.

\begin{tabular}{|c|c|c|c|}
\hline $\begin{array}{l}\text { Vehof, J.W. et al. } \\
{[178](2000)}\end{array}$ & $\begin{array}{l}\text { Implantation of CaP-coated titanium fiber } \\
\text { mesh (pore size } 250 \mu \mathrm{m}, 86 \% \text { porosity) } \\
\text { loaded with osteogenic cells into the back of } \\
\text { rats. }\end{array}$ & $\begin{array}{l}\text { None of the CaP-coated and non-coated } \\
\text { meshes alone supported bone formation } \\
\text { after } 6 \text { weeks. After } 8 \text { weeks bone } \\
\text { formation was observed in CaP coated } \\
\text { meshes. }\end{array}$ & $\begin{array}{l}\text { The combination of Ti mesh with } \\
\text { osteogenic cells can generate bone } \\
\text { formation, and CaP has a beneficial } \\
\text { effect on bone formation. }\end{array}$ \\
\hline $\begin{array}{l}\text { Habibovic, P. et al. } \\
\text { [179] (2005) }\end{array}$ & $\begin{array}{l}\text { Implantation of porous Ti6Al4V and OCP } \\
\text { coated-Ti6Al4V produced by a positive } \\
\text { replica technique (pore size } 400-1300 \mu \mathrm{m} \text {, } \\
79 \pm 5 \% \text { porosity) into the femora and back } \\
\text { muscle of goats. }\end{array}$ & $\begin{array}{l}\text { OCP coated-Ti6Al4V showed a higher } \\
\text { bone ingrowth and ectopic bone } \\
\text { formation amount than uncoated } \\
\text { Ti6Al4V. }\end{array}$ & $\begin{array}{l}\text { OCP posses high osteoconductive } \\
\text { potential. The coating was fully } \\
\text { replaced by newly formed bone after } \\
12 \text { weeks. }\end{array}$ \\
\hline $\begin{array}{l}\text { Hartman, E.H.M. } \\
\text { et al. [180] } \\
(2005)\end{array}$ & $\begin{array}{l}\text { Implantation of RBM cells loaded titanium } \\
\text { fiber mesh (fiber } \varnothing 50 \mu \mathrm{m}, 86 \% \text { porosity) } \\
\text { and porous CaP into the back muscle in rats. }\end{array}$ & $\begin{array}{l}\text { After } 6 \text { weeks limited bone ingrowth } \\
\text { inside the cell-loaded Ti fiber mesh was } \\
\text { found. The CaP group exhibited more } \\
\text { bone formation. }\end{array}$ & $\begin{array}{l}\text { RBM cell-loaded CaP is much more } \\
\text { osteoconductive than RBM cell- } \\
\text { loaded Ti fiber mesh. }\end{array}$ \\
\hline $\begin{array}{l}\text { Kroese-Deutman, } \\
\text { H.C. et al.[181] } \\
(2005)\end{array}$ & $\begin{array}{l}\text { Implantation of RGD-loaded Ti fiber } \\
\text { meshes (fiber } \varnothing 45 \mu \mathrm{m} \text {, porosity > 86\%) } \\
\text { into the cranium of rabbits. }\end{array}$ & $\begin{array}{l}\text { RGD-Ti scaffolds exhibited higher bone } \\
\text { formation and bone ingrowth. }\end{array}$ & $\begin{array}{l}\text { RGD in combination with Ti fiber } \\
\text { mesh produces a positive effect on } \\
\text { bone formation. }\end{array}$ \\
\hline $\begin{array}{l}\text { van der Dolder, J. } \\
\text { et al. [182] } \\
\text { (2003) }\end{array}$ & $\begin{array}{l}\text { Implantation of RBM stromal cells loaded } \\
\text { titanium fiber mesh (pore size } 250 \mu \mathrm{m}, 86 \% \\
\text { porosity) into cranial defects in rats. }\end{array}$ & $\begin{array}{l}\text { RBM cells enhanced the initial bone } \\
\text { formation and union of the skull bone } \\
\text { with bone inside the Ti fiber mesh only } \\
\text { occurred in the cell-loaded scaffolds. }\end{array}$ & $\begin{array}{l}\text { Bone compatibility of cell-loaded } \mathrm{Ti} \\
\text { fiber mesh is excellent. }\end{array}$ \\
\hline $\begin{array}{l}\text { Vehof, J.W. et al. } \\
\text { [183] } \\
\text { (2002) }\end{array}$ & $\begin{array}{l}\text { Implantation of transforming growth factor } \\
\beta \text {-I-loaded titanium fiber mesh (pore size } \\
250 \mu \mathrm{m}, 86 \% \text { porosity) with and without } \\
\text { Ca-P coating into cranial defects in rabbits. }\end{array}$ & $\begin{array}{l}\text { Bone ingrowth into fiber mesh was } \\
\text { observed, however, penetration inside the } \\
\text { mesh porosity was limited. }\end{array}$ & $\begin{array}{l}\text { In the Ti-TGF- } \beta \text {-I close bone contact } \\
\text { was observed and bone appeared to } \\
\text { be denser than in Ti-CaP and } \mathrm{Ti} \\
\text { porous scaffold. }\end{array}$ \\
\hline $\begin{array}{l}\text { Kroese-Deutman, } \\
\text { H.C. et al. } \\
\text { [184] (2008) }\end{array}$ & $\begin{array}{l}\text { Implantation of a Ti fiber mesh (fiber } \varnothing 45 \\
\mu \mathrm{m} \text {, porosity }>86 \% \text { ) loaded with platelet- } \\
\text { rich plasma (PRP) into a rabbit segmental } \\
\text { radial defect. }\end{array}$ & $\begin{array}{l}\text { Bone ingrowth observed after } 12 \text { weeks. } \\
\text { Newly formed bone was in direct contact } \\
\text { with the Ti surface. }\end{array}$ & $\begin{array}{l}\text { PRP loaded Ti scaffold exhibit a } \\
\text { beneficial effect on bone formation. }\end{array}$ \\
\hline $\begin{array}{l}\text { Sargeant, T.D. } \\
\text { et al. [185] } \\
\text { (2008) }\end{array}$ & $\begin{array}{l}\text { In vitro colonization evaluation of mouse } \\
\text { osteoblastic cells on a Ti foam-peptide } \\
\text { amphiphile containing phosphoserine } \\
\text { residues and the RGDS epitope. }\end{array}$ & $\begin{array}{l}\text { Bioactivity and high cell biocompatibility } \\
\text { was accomplished in the RGDS-modified } \\
\text { construct. }\end{array}$ & $\begin{array}{l}\text { RGDS epitope concentrations used in } \\
\text { the nanofiber networks demonstrated } \\
\text { significant cell migration into the } \\
\text { hybrids, proliferation and } \\
\text { differentiation into osteoblasts. }\end{array}$ \\
\hline $\begin{array}{l}\text { Chen, F. et al. } \\
\text { [186] (2007) }\end{array}$ & $\begin{array}{l}\text { Implantation of osteoblasts precursor cells } \\
\text { into Ti mesh-coral composite scaffold into } \\
\text { the backs of nude mice. }\end{array}$ & $\begin{array}{l}\text { Bone ingrowth observed after } 2 \text { months. } \\
\text { New bone formed integrated well into the } \\
\text { Ti mesh. }\end{array}$ & $\begin{array}{l}\text { Ti mesh-coral composite scaffold } \\
\text { with osteoblasts precursors cells is an } \\
\text { efficient means to engineer segmental } \\
\text { bone, processing the desired shape } \\
\text { and mechanical strength. }\end{array}$ \\
\hline
\end{tabular}

HA: Hydroxyapatite; Si-HA: Silicon-substituted hydroxyapatite; OCP: Octacalcium phosphate; RBM: Rat bone marrow; CaP: Calcium phosphate; RGD: Arginyl-glycyl-aspartyl peptide; RGDS: Arg-gly-Asp-Ser synthetic peptide. 
Table 14. Preclinical studies using Ta-hybrids scaffolds.



OCP: Octacalcium phosphate; BCA: Bone-like carbonated apatite; BIC: Bone-implant contact; rhBMP-2: Recombinant human bone morphogenetic protein-2; COLLOSS ${ }^{\circledR}$ : Bovine extracellular matrix product containing native BMPs; $\mu \mathrm{CT}$ : micro-computer tomography. 
Table 15. Clinical studies using titanium-ceramic, titanium-polymer, or cell loaded or autologous bone graft loaded titanium scaffolds.

\begin{tabular}{|c|c|c|c|}
\hline Author & Animal model \& implantation site & Clinical outcomes & Demonstrated properties \\
\hline $\begin{array}{l}\text { Thalgott, J.S. } \\
\text { et al. [196] } \\
\text { (2002) }\end{array}$ & $\begin{array}{l}\text { Implantation of MOSS Ti mesh cages } \\
\text { (DePuy Acromed, Raynham, MA) filled by } \\
\text { coralline HA and demineralized bone matrix } \\
\text { into } 50 \text { patients ( } 28 \text { to } 72 \text { years). }\end{array}$ & $\begin{array}{l}\text { A solid fusion rate of } 96 \% \text { was achieved. } \\
\text { Mean pain decrease was } 60 \% \text { overall. A total } \\
\text { of } 70 \% \text { of all patients either returned to work } \\
\text { or to home activities after } \approx 8 \text { months after } \\
\text { surgery. }\end{array}$ & $\begin{array}{l}\text { The combination of titanium mesh } \\
\text { cages, coralline hydroxyapatite and } \\
\text { demineralized bone matrix is effective } \\
\text { for anterior interbody fusion of the } \\
\text { lumbar spine. }\end{array}$ \\
\hline $\begin{array}{l}\text { Thalgott, J.S. } \\
\text { et al.[197] } \\
\text { (2003) }\end{array}$ & $\begin{array}{l}\text { Implantation of a cylindrical Ti mesh cages } \\
\text { (DePuy Acromed, Raynham, MA) filled } \\
\text { with local bone graft into } 26 \\
\text { nonmyleopathic patients ( } 34 \text { to } 81 \text { years). }\end{array}$ & $\begin{array}{l}\text { After } 64 \text { months } 80.7 \% \text { had an excellent or } \\
\text { good clinical outcome, yielding a fusion rate } \\
\text { of } 100 \% \text {. All cages remained intact with no } \\
\text { evidence of cage settling or collapse. }\end{array}$ & $\begin{array}{l}\text { Ti mesh cages filled with local bone } \\
\text { graft and rigid anterior plating is } \\
\text { effective for cervical reconstruction } \\
\text { after corpectomy and a viable } \\
\text { alternative to the use of fibular strut } \\
\text { allograft. }\end{array}$ \\
\hline $\begin{array}{l}\text { Thongtrangan, I. } \\
\text { et al. [198] } \\
\text { (2003) }\end{array}$ & $\begin{array}{l}\text { Implantation of a Ti vertebral body } \\
\text { expandable cage filled with autograft, } \\
\text { allograft and calcium phosphate into } 15 \\
\text { patients ( } 30 \text { to } 79 \text { years). }\end{array}$ & $\begin{array}{l}\text { Vertebral column defects could be } \\
\text { reconstructed without significant } \\
\text { complications after the mean follow-up time } \\
\text { of } 12.6 \text { months. }\end{array}$ & $\begin{array}{l}\text { The Ti cage provides an additional } \\
\text { means of achieving reduction of } \\
\text { kyphotic deformity and stabilization } \\
\text { after tumor resection. }\end{array}$ \\
\hline $\begin{array}{l}\text { Niu, C.C. et al. } \\
\text { [199] (2005) }\end{array}$ & $\begin{array}{l}\text { Implantation of a Ti alloy cervical spinal } \\
\text { cage (VIGOR }{ }^{\mathrm{TM}} \text {, Central Medical Tech., } \\
\text { Taiwan) filled with tricalcium phosphate } \\
\text { granules (Osteograft-S, Kyocera Co., Japan) } \\
\text { into } 54 \text { patients ( } 35 \text { to } 66 \text { years). }\end{array}$ & $\begin{array}{l}87 \% \text { of the patients exhibited satisfactory } \\
\text { clinical outcome after } 3 \text { years of follow-up. } \\
\text { Successful fusion was obtained in } 90.5 \% \text { of } \\
\text { the operated discs. }\end{array}$ & $\begin{array}{l}\text { The porous-coated Ti alloy cage } \\
\text { provided adequate mechanical support } \\
\text { and stability in the disc space and an } \\
\text { excellent fusion result without } \\
\text { subsidence of disc. }\end{array}$ \\
\hline $\begin{array}{l}\text { Chuang, H.C. } \\
\text { et al. [200] } \\
\text { (2006) }\end{array}$ & $\begin{array}{l}\text { Implantation of Ti mesh cages (TMCs) } \\
\text { (Mos Miami, UK) filled with autologous } \\
\text { bone graft and triosite (calcium phosphate } \\
\text { ceramics) into } 15 \text { patients (19 to } 69 \text { years). }\end{array}$ & $\begin{array}{l}11 \text { patients experienced improvement of } \\
\text { clinical neurological symptoms, } 3 \text { patients } \\
\text { remained the same, and } 1 \text { patient became } \\
\text { worse. }\end{array}$ & $\begin{array}{l}\text { The clinical results of the study are } \\
\text { acceptable. TMCs appear to provide an } \\
\text { acceptable way to reconstruct the } \\
\text { anterior column after corpectomy. }\end{array}$ \\
\hline $\begin{array}{l}\text { Boden, S.D. } \\
\text { et al. [201] } \\
\text { (2000) }\end{array}$ & $\begin{array}{l}\text { Implantation of a Ti interbody fusion cages } \\
\text { filled with rhBMP-2/collagen into } 14 \\
\text { patients with single-level lumbar } \\
\text { degenerative disc disease. }\end{array}$ & $\begin{array}{l}\text { All patients of the rhBMP- } 2 \text { group achieved } \\
\text { true interbody fusion after } 24 \text { months, while } \\
2 \text { of the } 3 \text { patients treated with autogenous } \\
\text { bone graft deemed to be fused. }\end{array}$ & $\begin{array}{l}\text { The arthrodesis was found to occur } \\
\text { more reliably in patients treated with } \\
\text { rhBMP-2 filled fusion cages than in } \\
\text { controls treated with autogeneous bone } \\
\text { graft. }\end{array}$ \\
\hline $\begin{array}{l}\text { Regnér, L. et al. } \\
\text { [202] (1998) }\end{array}$ & $\begin{array}{l}\text { Implantation of a Ti fiber mesh allocated on } \\
\text { the undersurface of a tibial prosthesis coated } \\
\text { and un coated with HA/TCP into } 36 \text { patients } \\
\text { undergoing total knee arthroplasty. }\end{array}$ & $\begin{array}{l}\text { After } 2 \text { years, the HA/TCP tibial components } \\
\text { displayed smaller anterior-posterior tilt and } \\
\text { less subsidence. }\end{array}$ & $\begin{array}{l}\text { HA/TCP coating on the undersurface } \\
\text { of the tibial component improved the } \\
\text { stability and seemed to improve the } \\
\text { quality at the interface between the } \\
\text { tibial component and the bone. }\end{array}$ \\
\hline $\begin{array}{l}\text { Hibi, H. et al. } \\
\text { [203] (2006) }\end{array}$ & $\begin{array}{l}\text { Implantation of one Ti mesh plate (Stryker, } \\
\text { Kalamazoo, MI) tissue-engineered with } \\
\text { platelet-rich plasma and autologous } \\
\text { mesenchymal stem cells in an alveolar cleft } \\
\text { osteoplasty of a 9-year-old female patient. }\end{array}$ & $\begin{array}{l}\text { TEOM regenerated the bone in the alveolar } \\
\text { cleft defect without donor-site morbidity } \\
\text { resulting from the autologous bone graft. }\end{array}$ & $\begin{array}{l}\text { The Ti scaffold facilitated a rigid space } \\
\text { without disturbing the blood supply } \\
\text { from the overlying flaps, but needed to } \\
\text { be removed before tooth eruption. }\end{array}$ \\
\hline
\end{tabular}

rhBMP-2: Recombinant human bone morphogenetic protein-2; HA: Hydroxyapatite; TCP: Tricalcium phosphate; TEOM: Tissueengineered osteogenic material. 
Table 15 lists the data derived from some clinical studies using hybrid Ti constructs. Although the various approaches used in bone tissue engineering result in increased bone formation, there is a lack of long-term data able to elucidate how long this de novo bone formation can be maintained. Formal examination of these clinical cases is pending. Moreover, there are a number of challenges to be overcome in the transition from preclinical studies in experimental animals to clinical trials in humans. In order to allow comparisons between different preclinical studies and their outcomes, it is essential that animal models and methods to evaluate the achieved results become standardized to accomplish the accumulation of reliable data leading to the development of intelligent constructs. Furthermore, it should be kept in mind that most of the cell-loaded scaffolds studies were performed using young adult or even fetal animal cells and not with cells from elderly patients. Therefore, extensive research will be needed to determine if results can be extended to the human situation and used in a clinical situation for treating human bone defects.

\section{Summary}

Porous metallic scaffolds are used in tissue engineering to replace damaged hard tissues in order to restore its functionality. These structural scaffolds possess an imposed pore structure and interconnectivity and are designed to maintain their shape and strength through the process of repair of the injured bone. For the long-term replacement of bone defects porous metallic scaffolds offer the advantage of interfacial porosity as well as permanent structural framework. They can be made by a number of processes (e.g. powder metallurgy, decomposition of foaming agents, replication, rapid prototyping technologies, among many others). Enormous progress has been made in the development of metallic scaffolds by rapid prototyping techniques and many researchers and surgeons believe that instead of biodegradable scaffolds, biochemically-modified porous metallic scaffolds are more suitable for the development of implants for load-bearing applications. To date, there are many in vivo and in vitro tissue-culturing approaches for bone repair using metallic scaffolds with macro-porous structure. Porous metallic structures have been tested as a bone-engineered construct using the cell-based and the growth-factor-based strategies. It has been also demonstrated that coating the metallic scaffolds with various proteins such as collagen, RGD-peptide, vibronectin and fibronectin leads to accelerated osseointegration and enhanced bone formation in vivo. Future directions of research in this field will probably focus on the efficient combinations of osteoinductive materials, osteoinductive growth factors and cell-based tissue regeneration approach using composite constructs carriers to reconstruct and repair hard tissues. The goal is to obtain a functional replacement of the injured hard tissue in a procedure that avoids the step of bone harvesting. Therefore, a perfectly controlled hybrid scaffold still remains to be developed.

\section{Acknowledgements}

The present work was supported by Priority Assistance for the Formation of Worldwide Renowned Centers of Research - The Global COE Program (Project: Center of Excellence for Advanced Structural and Functional Materials Design) from the Ministry of Education, Culture, Sports, Science and Technology (MEXT), Japan. 


\section{References and Notes}

1. Mathieu, L.M.; Mueller, T.L.; Bourban, P.-E.; Pioletti, D.P.; Müller, R.; Månson, J.-A.E. Architecture and properties of anisotropic polymer composite scaffolds for bone tissue engineering. Biomaterials 2006, 27, 905-916.

2. Robisnson, R.A.; Watson, M.L. Collagen-crystal relationship in bone as seen in the electron microscope. Anatom. Rec. 1952, 114, 383-392.

3. Gerhon, R.P.; Fedarko, N.S.; Hefferan, T.E.; Bianco, P.; Vetter, U.K.; Grzesik, W.; Friedenstein, A.; van der Pluijm, G.; Mintz, K.P.; Young, M.F.; Kerr, J.M.; Ibaraki, K.; Heegaard, A.M.; Structure and molecular regulation of bone matrix proteins. J. Bone Miner. Res. 1993, 8 (Suppl 2), S483-S487.

4. Marks, S.C., Jr.; Odgren, P.R. Structure and development of the skeleton. In Principles of Bone Biology, 2nd ed.; Bilezikian, J.P., Raisz, L.G., Rodan, G.A., Eds.; Academic Press: San Diego, CA, USA, 2002; pp. 3-15.

5. Buckwalter, J.A.; Glimcher, M.J.; Cooper, R.R.; Recker, R. Bone biology I: Structure, blood supply, cells, matrix and mineralization. Instr. Course Lect. 1996, 45, 371-386.

6. Katz, E.P.; Li, S.-T. Structure and function of bone collagen fibrils. J. Mol. Biol. 1973, 80, 1-15.

7. Young, R.A. Some aspects of crystal structural modeling of biological apatites. In Physicochemie et ccristallographie des apatites d'interet biologique; Centre National de la Recherche Scientifique; C.N.S.R. Publication: Paris, France, 1975; No. 230, pp. 21-40.

8. $\quad$ Fung, Y. Biomechanics: Mechanical Properties of Living Tissue, 2nd ed.; Springer-Verlag: New York, NY, USA, 1993; pp. 225-229.

9. Evans, F.G. Mechanical Properties of Bone, 1st ed.; Charles C. Thomas Co.: Springfield, IL, USA, 1971; pp. 272-310.

10. Reilly, D.T.; Burstein, A.H. The mechanical properties of cortical bone. J. Bone Joint Surg. Am. 1974, 56, 1001-1022.

11. Rho, J.Y.; Kuhn-Spearing, L.; Zioupos, P. Mechanical properties and the hierarchical structure of bone. Med. Eng. Phys. 1998, 20, 92-102.

12. Guo, X.E. Mechanical properties of cortical bone and cancellous tissue. In Bone Mechanics Handbook, 2nd ed.; Cowin, S.C., Ed.; CRC Press LLC: Boca Raton, FL, USA, 2001; pp.10:1$10: 23$.

13. Reilly, D.T.; Burstein, A.H.; Frankel, V.H. The elastic modulus for bone. J. Biomech. 1974, 7, 271-275.

14. Wirtz, D.C.; Schiffers, N.; Pandorf, T.; Radermacher, K.; Weichert, D.; Forst, R. Critical evaluation of known bone material properties to realize anisotropic FE-simulation on the proximal femur. J. Biomech. 2000, 33, 1325-1330.

15. Morgan, E.F.; Bayraktar, H.H.; Keaveny, T.M. Trabecular bone modulus-density relationships depend on anatomic site. J. Biomech. 2003, 36, 897-904.

16. Wainwright, S.A.; Biggs, W.D.; Currey, J.D.; Gosline, J.M. Mechanical Design in Organisms, 1st ed.; Princeton University Press: Princeton, NJ, USA, 1976.

17. Eckardt, I.; Hein, H.-J. Quantitative measurements of the mechanical properties of human bone tissues by scanning acoustic microscopy. Annals Biomed. Eng. 2001, 29, 1043-1047. 
18. McKoy, B.E.; An, Y.H.; Friedman, R.J. Factors affecting the strength of the bone-implant interface. In Mechanical Testing of Bone and the Bone-Implant-Interface, 1st ed.; An, Y.A., Draughn, R.A., Eds.; CRC Press: Boca Raton, FL, USA, 2000; pp. 439-461.

19. Rho, J.Y.; Ashman, R.B.; Turner, C.H. Young's modulus of trabecular and cortical bone material: ultrasonic and microtensile measurements. J. Biomech. 1993, 26, 111-119.

20. Currey, J.D. Tensile yield in compact bone is determined by strain, post-yield behavior by mineral content. J. Biomech. 2004, 37, 549-556.

21. Ford, C.M.; Keaveny, T.M. The dependence of shear failure properties of trabecular bone on apparent density and trabecular orientation. J. Biomech. 1996, 29, 1309-1317.

22. Yaszemski, M.J.; Payne, R.G.; Hayes, W.C.; Langer, R.; Mikos, A.G. Evolution of bone transplantation: Molecular, cellular and tissue strategies to engineer human bone. Biomaterials 1996, 17, 175-185.

23. Lane, J.M.; Tomin, E.; Bostrom, M.P.G. Biosynthetic bone grafting. Clin. Orthop. Relat. Res. 1999, 367 (Suppl), S107-S117.

24. Bucholz, R.W. Nonallograft osteoconductive bone graft substitutes. Clin. Orthop. Relat. Res. 2002, 395, 44-52.

25. Lieberman, J.R.; Daluiski, A.; Einhorn, T.A. The role of growth factors in the repair of bone. Biology and clinical applications. J. Bone Joint Surg. Am. 2002, 84A, 1032-1044.

26. Westerhuis, R.J.; van Bezooijen, R.L.; Kloen, P. Use of bone morphogenetic proteins in traumatology. Injury 2005, 36, 1405-1412.

27. Bruder, S.P.; Fox, B.S. Tissue engineering of bone. Cell based strategies. Clin. Orthop. Relat. Res. 1999, 367 (Suppl), S68-S83.

28. Hutmacher, D.W.; Garcia, A.J. Scaffold based bone engineering by using genetically modified cells. Gene 2005, 347, 1-10.

29. Kimelman, N.; Pelled, G.; Helm, G.A.; Huard, J.; Schwarz, E.M.; Gazit, D. Review: Gene and stem cell-based therapeutics for bone regeneration and repair. Tissue Eng. 2007, 13, 1135-1150.

30. Alam, S.; Ueki, K.; Marukawa, K.; Ohara, T.; Hase, T.; Takazakura, D.; Nakagawa, K. Expression of bone morphogenetic protein 2 and fibroblast growth factor 2 during bone regeneration using different implant materials as an onlay bone graft in rabbit mandibles. Oral Surg. Oral Med. Oral Path. Oral Radiol. Endod. 2007, 103, 16-26.

31. Wozney, J.M.; Rosen, V.; Celeste, A.J.; Mitsock, L.M.; Whitters, M.J.; Kriz, R.W.; Hewick, R.M.; Wang, E.A. Novel regulators of bone formation: molecular clones and activities. Science 1988, 242, 1528-1534.

32. Salgado, A.J.; Countinho, O.P.; Reis, R.L. Bone tissue engineering: State of the art and future trends. Macromol. Biosci. 2004, 4, 743-765.

33. Jones, J.R.; Poologasundarampillai, G.; Atwood, R.C.; Bernard, D.; Lee, P.D. Non-destructive quantitative $3 \mathrm{D}$ analysis for the optimization of tissue scaffolds. Biomaterials 2007, 28, 1404-1413.

34. Wang, G.; Snyder, D.L.; Vannier, M.W. Local computed tomography via iterative deblurring. Scanning 1996, 18, 582-588. 
35. Sassov, A.; Buelens, E. Non-Destructive 3-Dimensional microtomography for metallic foams. In Microstructural Investigation and Analysis Series EUROMAT 99, 1st ed.; Jouffrey, B., Ed.; Wiley-VCH Verlag GmbH: Weinheim, Germany, 2000; Part I, pp. 57-62.

36. Ryan, G.E.; Pandit, A.S.; Apatsidis, D.P. Porous titanium scaffolds fabricated using a rapid prototyping and powder metallurgy technique. Biomaterials 2008, 29, 3625-3635.

37. Jaecques, S.V.N.; Van Osterwyck, H.; Muraru, L.; Van Cleynenbreugel, T.; De Smet, E.; Wevers, M.; Naert, I.; Vander Sloten, J. Individualised, micro CT-based finite element modeling as a tool for biomechanical analysis related to tissue engineering of bone. Biomaterials 2004, 25 , 1683-1696.

38. Cho, Y.; Gosain, A. Biomaterials in craniofacial reconstruction. Clin. Plastic Surg. 2004, 31, 377-385.

39. Elshahat, A.; Shermak, M.; Inoue, N.; Chao, E.; Manson, P. The use of novabone and norian in cranioplasty: A comparative study. J. Craniof. Surg. 2004, 15, 483-489.

40. Eppley, B. Invited discussion: A comparison of resistance to fracture among four commercially available forms of hydroxyapatite cement. Annals Plastic Surg. 2005, 55, 93-100.

41. Greenberg, B.; Scheneider, S. Alloplastic reconstruction of large cranio-orbital defects: A comparative evaluation. Annals Plastic Surg. 2005, 55, 43-51.

42. Moreira-Gonzalez, A.; Jackson, I.; Miyawaki, T.; Barakat, K.; Dinick, V. Clinical outcome in cranioplasty: Critical review in long-term follow-up. J. Craniof. Surg. 2003, 14, 144-153.

43. Mishra, S.; Knothe-Tate, M.L. Effect of lacunocanalicular architecture on hydraulic conductance in bone tissue: Implications for bone health and evolution. Anat. Rec. 2003, 273A, 752-762.

44. Freyman, T.M.; Yannas, I.V.; Gibson, L.J. Cellular materials as porous scaffolds for tissue engineering. Prog. Mater. Sci. 2001, 46, 273-282.

45. Boyan, B.D.; Hummert, T.W.; Dean, D.D.; Schwartz, Z. Role of materials surfaces in regulating bone and cartilage cell response. Biomaterials 1996, 17, 137-146.

46. Sumner, D.R.; Turner, T.M.; Igloria, R.; Urban, R.M.; Galante, J.O. Functional adaptation and ingrowth of bone vary as a function of hip implant stiffness. J. Biomech. 1998, 31, 909-917.

47. Brunette, D.M.; Ratkay, J.; Chehroudi, B. The behavior of osteoblasts on micromachined surfaces. In Bone-Biomaterial Interface; Davies, J.E., Ed.; University of Toronto Press: Toronto, Canada, 1991; pp. 170-180.

48. Boyan, B.D.; Hummert, T.W.; Kieswetter, K.; Schraub, D.; Dean, D.D.; Schwartz, Z. Effect of titanium surface characteristics on chondrocytes and osteoblasts in vitro. Cells Mater. 1995, 5, 323-335.

49. Buser, D.; Schenk, R.K.; Steinemann, S.; Fiorellini, J.P.; Fox, C.H.; Stich, H. Influence of surface characteristics on bone integration of titanium implants. A histomorphometric study in miniature pigs. J. Biomed. Mater. Res. 1991, 25, 889-902.

50. Schwartz, Z.; Martin, J.Y.; Dean, D.D.; Simpson, J.; Cohran, D.L.; Boyan, B.D. Effect of titanium surface roughness on chrondrocyte proliferation, matrix production, and differentiation depends on the state of cell maturation. J. Biomed. Mater. Res. 1996, 30, 145-155.

51. Jansson, E.; Källtorp, M.; Johansson, A.; Tengvall, P.; Thomsen, P. On the formation of fibrous capsule and fluid space around machined and porous blood plasma clot coated titanium. $J$. Mater. Sci. Mater. Med. 2001, 12, 1019-1024. 
52. Liu, X.; Chu, P.K.; Ding, C. Surface modification of titanium, titanium alloys, and related materials for biomedical applications. Mat. Sci. Eng. R 2004, 47, 49-121.

53. Duan, K.; Wang, R. Surface modifications of bone implants through wet chemistry. J. Mater. Chem. 2006, 16, 2309-2321.

54. Sitting, C.; Textor, M.; Spencer, N.D. Surface characterization of implant materials c.p. Ti, Ti6Al-7Nb and Ti-6Al-4V with different pretreatments. J. Mater. Sci. Mater. Med. 1999, 10, 35-46.

55. Ratner, B.D. The surface characterization of biomedical materials: How finely can we resolve surface structure? In Surface Characterization of Biomaterials; Ratner, B.D., Ed.; Elsevier: Amsterdam, Netherlands, 1988; pp. 13-36.

56. Sun, W.; Starly, B.; Nam, J.; Darling, A. Bio-CAD modeling and its applications in computeraided tissue engineering. Comput. Aided Des. 2005, 37, 1097-1114.

57. Leong, K.F.; Cheah, C.M.; Chua, C.K. Solid freeform fabrication of three-dimensional scaffolds for engineering replacement tissues and organs. Biomaterials 2003, 24, 2363-2378.

58. Liu, C.; Xia, Z.; Czernuszka, J.T. Design and development of three-dimensional scaffolds for tissue engineering. Chem. Eng. Res. Design 2007, 85A, 1051-1064.

59. Jacobs, J.J.; Skipor, A.K.; Patterson, L.M.; Hallab, N.J.; Paprosky, W.G.; Black, J.; Galante, J.O. Metal release in patients who have had a primary total hip arthroplasty. J. Bone Joint Surg. Am. 1998, 80, 1447-1458.

60. Bobyn, J.D.; Stackpool, G.J.; Hacking, S.A.; Tanzer, M.; Krygier, J.J. Characteristics of bone ingrowth and interface mechanics of a new porous tantalum biomaterial. J. Bone Joint Surg. Br. 1999, 81B, 907-914.

61. Bobyn, J.D.; Toh, K.K.; Hacking, S.A.; Tanzer, M.; Krygier, J.J. The tissue response to porous tantalum acetabular cups: A canine model. J Arthroplast. 1999, 14, 347-354.

62. Staiger, M.P., Pietak, A.M.; Huadmai, J.; Dias, G. Magnesium and its alloys as orthopedic biomaterials: A review. Biomaterials 2006, 27, 1728-1734.

63. Heublein, B.; Rohde, R.; Kaese, V.; Niemeyer, M.; Hartung, W.; Haverich, A. Biocorrosion of magnesium alloys: A new principal in cardiovascular implant technology? Heart 2003, 89, 651-656.

64. Erbel, R.; Di Mario, C; Bartunek, J.; Bonnier, J.; de Bruyne, B.; Eberli, F.R.; Erne, P.; Haude, M.; Heublein, B. Temporary scaffolding of coronary arteries with bioabsorbable magnesium stents: A prospective, non-randomised multicentre trial. Lancet 2007, 369, 1869-1875.

65. Witte, F.; Kaese, V.; Switzer, H.; Meyer-Lindenberg, A.; Wirth, C.J.; Windhag, H. In vivo corrosion of four magnesium alloys and the associated bone response. Biomaterials 2005, 26, 3557-3563.

66. Witte, F.; Fischer, J.; Nellesen, J.; Crostack, H.A.; Kaese, V.; Pisch, A.; Beckmann, F.; Windhagen, H. In vitro and in vivo corrosion measurements of magnesium alloys. Biomaterials 2006, 27, 1013-1018.

67. Li, Z.; Gu, X.; Lou, S.; Zheng, Y. The development of binary Mg-Ca alloys for use as biodegradable materials within bone. Biomaterials 2008, 29, 1329-1344.

68. Saris, N.E.; Mervaala, E.; Karppanen, H.; Khawaja, J.A.; Lewenstam, A. Magnesium: An update on physiological, clinical and analytical aspects. Clin. Chim. Acta 2000, 294, 1-26. 
69. Li, L.; Gao, J.; Wang, Y. Evaluation of cytotoxicity and corrosion behavior of alkali-heat-treated magnesium in simulated body fluid. Surf. Coat. Technol. 2004, 185, 92-98.

70. Zhang, E.L.; Xu, L.P.; Yang, K. Formation by ion plating of Ti-coating on pure Mg for biomedical applications. Scripta Mater. 2005, 53, 523-527.

71. Zhang, E.L.; Xu, L.P.; Yu, G.; Pan, F.; Yang, K. In vivo evaluation of biodegradable magnesium alloy bone implant in the first 6 months implantation. J. Biomed. Mater. Res. A 2009, in press, doi: 10.1002/jbm.a.32132.

72. Davies, J.E. Bone bonding at natural and biomaterial surfaces. Biomaterials 2007, 89, 5058-5067.

73. Okazaki,Y. A new Ti-15Zr-4Nb-4Ta alloy for medical applications. Solid State Mater. Sci. 2001, 5, 45-53.

74. Zdeblick, T.A.; Phillips, F.M. Interbody cage devices. Spine J. 2003, 28, S2-S7.

75. Jansen, J.A.; Vehof, J.W.; Ruhe, P.Q.; Kroze-Deutman, H.; Kuboki, Y.; Takita, H.; Hedberg, E.L.; Mikos, A.G. Growth factors-loaded scaffolds for bone engineering. J. Control Release 2005, 101, 127-136.

76. Zhang, W.; Walboomers, X.F.; van Kuppevelt, T.H.; Daamen, W.F.; Bian, Z.; Jansen, J.A. The performance of human dental pulp stem cells on different three-dimensional scaffolds materials. Biomaterials 2006, 27, 5658-5668.

77. Prymaka, O.; Bogdanskib, D.; Köllerb, M.; Esenweinb, S.A.; Muhrb, G.; Beckmann, F.; Donath, T.; Assad, M.; Epple, M. Morphological characterization and in vitro biocompatibility of a porous nickel-titanium alloy. Biomaterials 2005, 26, 5801-5807.

78. Greiner, L.C.; Oppenheimer, M.S.; Dunand, D.C. High strength, low stiffness, porous NiTi with superelastic properties. Acta Biomater. 2005, 1, 705-716.

79. Tarnita, D.; Tarnita, D.N.; Bîzdoaca, N.; Mîndrila, I.; Vasilescu, M. Properties and medical applications of shape memory alloys. Romanian J. Morphol. Embryol. 2009, 50, 15-21.

80. Assad, M.; Chernyshov, A.; Leroux, M.A.; Rivard, C.H. A new porous titanium-nickel alloy: Part 1. Cytotoxicity and genotoxicity evaluation. Biomed. Mater. Eng. 2002, 12, 225-237.

81. Michiardi, A.; Aparicio, C.; Planell, J.A.; Gil, F.J. New oxidation treatment of NiTi shape memory alloys to obtain Ni-free surface and to improve biocompatibility. J. Biomed. Mater. Res. B 2006, 77, 249-256.

82. Armitage, D.A.; Parker, T.L.; Grant, D.M. Biocompatibility and hemocompatibility of surfacemodified NiTi alloys. J. Biomed. Mater. Res. A 2003, 66, 129-137.

83. Kapanen, A.; Ryhanen, J.; Danilov, A.; Tuukkanen, J. Effect of nickel-titanium shape memory alloy on bone formation. Biomaterials 2001, 22, 2475-2480.

84. Firstov, G.S.; Vitchev, R.G.; Kumar, H.; Blanpain, B.; van Humbeeck, J. Surface oxidation of NiTi shape memory alloy. Biomaterials 2002, 23, 4863-4871.

85. Michiardi, A.; Aparicio, C.; Planell, J.A.; Gil, F.J. New oxidation treatment of NiTi shape memory alloys to obtain Ni-free surfaces and to improve biocompatibility. J. Biomed. Mater. Res. B 2006, 77, 249-256.

86. Suzuki, A.; Kanetaka, H.; Shimizu, Y.; Tomizuka, R.; Hosoda, H.; Miyazaki, S.; Okuno, O.; Igarashi, K.; Mitani, H. Orthodontic buccal tooth movement by nickel-free titanium-based shape memory and superelastic alloy wire. Angle Orthod. 2006, 76, 1041-1046. 
87. Giesen, E.B.; Lamerigts, N.M.; Verdosnschot, N.; Buma, P.; Schreurs, B.W.; Huiskes, R. Mechanical characteristics of impacted morselised bone grafts used in revision of total hip arthroplasty. J. Bone Jt. Surg. Br. 1999, 81, 1052-1057.

88. Oh, I.H.; Nomura, N.; Masahashi, N.; Hanada, S. Mechanical properties of porous titanium compacts prepared by powder processing. Scripta Mater. 2003, 49, 1197-1202.

89. Martell, J.M.; Pierson, R.H.; Jacobs, J.J.; Rosenberg, A.G.; Maley, M.; Galante, J.O. Primary total hip reconstruction with a titanium fiber-coated prosthesis inserted without cement. $J$. Bone Joint Surg. Am. 1993, 75, 554-571.

90. Bram, M. High-porosity titanium, stainless steel, and superalloy parts. Adv. Eng. Mater. 2000, 2, 196-199.

91. Li, J.P.; Li, S.H.; de Groot, K.; Layrolle, P. Preparation and characterization of porous titanium. Key Eng. Mater. 2002, 218, 51-54.

92. Ducheyne, P; Martens, M. Orderly oriented wire meshes as porous coatings on orthopaedic implants. I: Morphology. Clin. Mater. 1986, 1, 59-67.

93. Li, B.Y.; Rong, L.J.; Li, Y.Y.; Gjunter, V.E. A recent development in producing porous NiTi shape memory alloys. Intermetallics 2000, 8, 881-884.

94. Miyao, R.; Omori, M.; Watari, F.; Yokoyama, A.; Matsuno, H.; Hirai, T. Kawasaki, T. Fabrication of functionally graded implants by spark plasma sintering and their properties. $J$. Japan Soc. Powder Metall. 2000, 47, 1239-1242.

95. Groza, J.R.; Zavaliangos, A. Sintering activation by external electrical field. Mater. Sci. Eng. A 2000, 287, 171-177.

96. Alvarez, K.; Hyun, S.K.; Nakano, T.; Umakoshi, Y.; Nakajima, H. In vivo osteocompatibility of Lotus-type porous nickel-free stainless steel in rats. Mater. Sci. Eng. C 2009, 29, 1182-1190.

97. Gu, Y.W.; Yong, M.S.; Tay, B.Y.; Lim, C.S. Synthesis and bioactivity of porous Ti alloy prepared by foaming with $\mathrm{TiH}_{2}$. Mater. Sci. Eng. $C$ 2009, in press, doi: 10.1016/j.msec.2008.11.003.

98. Tane, M.; Nakajima, H. Fabrication of porous magnesium with directional pores through use of hydrogen thermally decomposed from $\mathrm{MgH}_{2}$ powders during unidirectional solidification. $J$. Mater. Res. 2008, 23, 849-855.

99. Verdooren, A.; Chan, H.M.; Grenestedt, J.L.; Harmer, M.P.; Caram, H.S. Production of metallic foams from ceramic foam precursors. Adv. Eng. Mater. 2004, 6, 397-399.

100. Davies, N.G.; Teisen, J.; Schuh, C.; Dunand, D.C. Solid-state foaming of titanium by superplastic expansion of argon-filled pores. J. Mater. Res. 2001, 16, 1508-1519.

101. Dunand, D.C. Processing of titanium foams. Adv. Eng. Mater. 2004, 6, 369-376.

102. Ryan, G.; Pandit, A.; Apatsidis, D.P. Fabrication methods of porous metals for use in orthopaedic applications. Biomaterials 2006, 27, 2651-2670.

103. Svela, M.; Morberg, P.; Zicat, B.; Bruce, W.; Sonnabend, D.; Walsh, W.R. Morphometric and mechanical evaluation of titanium implant integration: Comparison of five surface structures. $J$. Biomed. Mater. Res. B 2001, 51, 15-22.

104. Rodriguez, J.A. Acetabular fixation options: Notes from the other side. J. Arthroplast. 2006, 21, 93-96. 
105. Engh, C.A.; Hopper, R.H., Jr. The odyssey of porous-coated fixation. J. Arthroplast. 2002, 17 (4, Suppl 1), 102- 107.

106. Engh, C.A.; Hopper, R.H., Jr. Long-term porous-coated cup survivorship using spikes, screws, and press-fitting for initial fixation. J. Arthroplast. 2004 , 19 (Suppl), 54-60.

107. Gaffey, J.L.; Callaghan, J.J.; Pedersen, D.R.; Goetz, D.D.; Sullivan, P.M.; Johnston, R.C. Cementless acetabular fixation at fifteen years: A comparison with the same surgeon's results following acetabular fixation with cement. J. Bone Joint Surg. 2004, 86A, 257-261.

108. Della Valle, C.J.; Berger, R.A.; Shott, S.; Rosenberg, A.G.; Jacobs, J.J.; Quigley, L., Galante, J.O. Primary total hip arthroplasty with a porous-coated acetabular component. J. Bone Joint Surg. 2004, 86A, 1217-1222.

109. Petersen, M.B.; Poulsen, I.H.; Thomsen, J.; Solgaard, S. The hemispherical Harris-Galante acetabular cup, inserted without cement. The results of an eight to eleven-year follow-up of one hundred and sixty-eight hips. J. Bone Joint Surg. 1999, 81, 219-224.

110. Valle, A.G.; Zoppi, A.; Peterson, M.G.; Salvati, E.A. Clinical and radiographic results associated with a modern, cementless modular cup design in total hip arthroplasty. J. Bone Joint Surg. 2004, 86A, 1998-2004.

111. Banhart, J. Manufacture, characterization and application of cellular metals and metal foams. Prog. Mater. Sci. 2001, 46, 559-632.

112. Ashely, S. Rapid Prototyping System. Mech. Eng. 1991, 113, 34-43.

113. Hutmacher, D.W.; Sittinger, M.; Risbud, M.V. Scaffold-based tissue engineering: Rationale for computer-aided design and solid free-form fabrication systems. Trends Biotechnol. 2004, 22, 354-362.

114. Leong, K.F.; Cheah, C.M.; Chua, C.K. Solid freeform fabrication of three-dimensional scaffolds for engineering replacement tissues and organs. Biomaterials 2003, 24, 2363-2378.

115. Li, J.P.; de Wijn, J.R.; van Blitterswijk, C.A.; de Groot, K. Porous $\mathrm{Ti}_{6} \mathrm{Al}_{4} \mathrm{~V}$ scaffolds directly fabricated by 3D fibre deposition technique: Effect of nozzle diameter. J. Mater. Sci. Mater. Med. 2005, 16, 1159-1163.

116. Curodeau, A.; Sachs, E.; Caldarise, S. Design and fabrication of cast orthopedic implants with freeform surface textures from 3-D printed ceramic shell. J. Biomed. Mater. Res. B 2000, 53, 525-535.

117. Murr, L.E.; Esquivel, E.V.; Quinones, S.A.; Gaytan, S.M.; Lopez, M.I.; Martinez, E.Y.; Medina, F.; Hernandez, D.H.; Martinez, E.; Stafford, S.W.; Brown, D.K.; Hoppe, T.; Meyers, W.; Lindhe, U.; Wicker, R.B. Microstructures and mechanical properties of electron beam-rapid manufactured Ti-6Al-4V biomedical prototypes compared to wrought Ti-6Al-4V. Mater. Char. 2009, 60, 96-105.

118. Mullen, L.; Stamp, R.C.; Brooks, W.K.; Jones, E.; Sutcliffe, C.J. Selective laser melting: A regular unit approach for the manufacture of porous titanium, bone ingrowth constructs, suitable for orthopedic applications. J. Biomed. Mater. Res. B 2009, in press, doi: 10.1002/jbm.b.31219.

119. Vandenbroucke, B.; Kruth, J.-P. Selective laser melting of biocompatible metals for rapid manufacturing of medical parts. Rapid Prototyp. J. 2007, 13, 196-203.

120. Ryan, G.E.; Pandit, A.S.; Apatsidis, D.P. Porous titanium scaffolds fabricated using a rapid prototyping and powder metallurgy technique. Biomaterials 2008, 29, 3625-3635. 
121. Li, X.; Wang, C.; Zhang, W.; Li, Y. Fabrication and characterization of porous $\mathrm{Ti}_{6} \mathrm{Al}_{4} \mathrm{~V}$ parts for biomedical applications using electron beam melting process. Mater. Lett. 2009, 63, 403-405.

122. Dinda, G.P.; Song, L.; Mazumder, J. Fabrication of $\mathrm{Ti}_{6} \mathrm{Al}_{4} \mathrm{~V}$ scaffolds by direct metal deposition. Metall. Mater. Trans. A 2008, 39A, 2914-2922.

123. Krishna, B.V.; Bose, S.; Bandyopadhyay, A. Low stiffness porous Ti structures for load-bearing implants. Acta Biomater. 2007, 3, 997-1006.

124. Xue, W.; Krishna, B.V.; Bandyopadhyay, A; Bose, S. Processing and biocompatibility evaluation of laser processed porous titanium. Acta Biomater. 2007, 3, 1007-1018.

125. Das, S.; Wohlert, M.; Beaman, J.J.; Bourell, D.L. Producing metals parts with selective laser sintering/hot isostatic pressing. JOM-J. Min. Met. Mat. Soc. 1998, 50, 17-20.

126. Geng, F.; Tan, L.; Zhang, B.; Wu, C.; He, Y.; Yang, J.; Yang, K. Study on $\beta$-TCP coated porous Mg as a bone tissue engineering scaffold material. J. Mater. Sci. Technol. 2009, 25, 123-129.

127. Witte, F.; Feyerabend, F.; Maier, P.; Fischer, J.; Störmer, M.; Blawert, C.; Dietzel, W.; Hort, N. Biomaterials 2007, 28, 2163-2174.

128. Crowninshield, R.D. Mechanical properties of porous metal total hip prostheses. Instr. Course Lect. 1986, 35, 144-148.

129. van den Dolder, J.; Jansen, J.A. Titanium fiber mesh: A nondegradable scaffold material. Eng. Funct. Skeletal Tissues 2007, 3, 69-80.

130. Dai, K.; Chu, Y. Studies and applications of NiTi shape memory alloys in the medical field in China. Biomed. Mater. Eng. 1996, 6, 233-240.

131. Likibi, F.; Chabot, G.; Assad, M.; Rivard, C.-H. Influence of orthopedic implant structure on adjacent bone density and on stability. Am. J. Orthop. 2008, 37, E78-E83.

132. Zhang, Y.; Ahn, P.B.; Fitzpatrick, D.C.; Heiner, A.D.; Poggie, R.A.; Brown, T.D. Interfacial frictional behavior: cancellous bone, cortical bone, and a novel tantalum biomaterial. $J$. Musculoskeletal Res. 1999, 3, 245-251.

133. Hacking, S.A.; Bobyn, J.D.; Toh, K.; Tanzer, M.; Krygier, J.J. Fibrous tissue ingrowth and attachment to porous tantalum. J. Biomed. Mater. Res. A 2000, 52, 631-638.

134. Rahbek, O.; Kold, S.; Zippor, B.; Overgard, S.; Soballe, K. Particle migration and gap healing around trabecular metal implants. Int. Orthop. 2005, 29, 368-374.

135. Adams, J.E.; Zobitz, M.E.; Reach, J.S.; An, K.N.; Lewallen, D.G.; Steinmann, S.P. Canine carpal joint fusion: A model for four-corner arthrodesis using a porous tantalum implant. J. Hand Surg. 2005, 30A, 1128-1135.

136. Zou, X.; Li, H.; Bünger, M.; Egund, N.; Lind, M.; Bünger, C. Bone ingrowth characteristics of porous tantalum and carbon fiber interbody devices: An experimental study in pigs. Spine J. 2004, 4, 99-105.

137. Tanzer, M.; Kantor, S.; Bobyn, J.D. Enhancement of bone growth into porous intramedullary implants using non-invasive low intensity ultrasound. J. Orthop. Res. 2001, 19, 195-199.

138. Meneghini, R.M.; Lewallen, D.G.; Hanssen, A.D. Use of porous tantalum metaphyseal cones for severe tibial bone loss during revision total knee replacement. J. Bone Joint Surg. Am. 2008, 90, 78-84.

139. Long, W.; Scuderi, G.R. Porous tantalum cones for large metaphyseal tibial defects in revision total knee arthroplasty. J. Arthroplast. 2009, in press, doi: 10.1016/j.arth.2008.08.011. 
140. Nadeau, M.; Séguin, C.; Theodoropoulos, J.S.; Harvey, E.J. Short term clinical outcome of a porous tantalum implant for the treatment of advanced osteonecrosis of the femoral head. McGill J. Med. 2007, 10, 4-10.

141. Tsao, A.K.; Roberson, J.R.; Christie, M.J.; Dore, D.D.; Heck, D.A.; Robertson, D.D.; Poggie, R.A. Biomechanical and clinical evaluation of a porous tantalum implant for the treatment of early-stage osteonecrosis. J. Bone Joint Surg. Am. 2005, 87A (Suppl 2), 22-27.

142. Durham, S.R.; McComb, J.G.; Levy, M.L. Correction of large $\left(>25 \mathrm{~cm}^{2}\right)$ cranial defects with "reinforced" hydroxyapatite cement: technique and complications. Neurosurgery 2003, 52, 842-845.

143. Shuler, M.S.; Rooks, M.D.; Roberson J.R. Porous tantalum implant in early osteonecrosis of the hip. J. Arthroplast. 2007, 22, 26-31.

144. Reifenrath, J.; Palm, C.; Müller, P.P.; Hauser, H.; Crostack, H.A.; Nellesen, J.; Bach, F.W; Besdo, D.; Rudert, M.; Witte, F. Subchondral plate reconstruction by fast degrading magnesium scaffolds influence cartilage repair in osteochondral defects. In Transactions of the $51^{\text {st }}$ Annual Meeting of the Orthopaedic Research Society (ORS), Washington, DC, USA, February 2005; Volume 30, S. 1347.

145. Witte, F.; Reifenrath, J.; Müller, P.P.; Crostack, H.-A.; Nellesen, J.; Bach, F.W.; Bormann, D.; Rudert, M. Cartilage repair on magnesium scaffolds used as a subchondral bone replacement. Materwiss. Werksttech. 2006, 37, 504-508.

146. Witte, F.; Ulrich, H.; Rudert, M.; Willbold, E. Biodegradable magnesium scaffolds: Part I: Appropriate inflammatory response. J. Biomed. Mater. Res. A 2007, 81, 748-756.

147. Witte, F.; Ulrich, H.; Palm, C.; Willbold, E. Biodegradable magnesium scaffolds: Part II: Periimplant bone remodeling. J. Biomed. Mater. Res. A 2007, 81, 757-765.

148. Matsuzaka, K.; Yoshinari, M.; Kokubu, E.; Shimono, M.; Yamada, Y.; Mabuchi, M.; Inoue, T. Bone formation in titanium porous scaffold with immobilization of BMP-2. J. Oral Tissue Eng. 2005, 2, 60-65.

149. Ponader, S.; von Wilmowsky, C.; Widenmayer, M.; Lutz, R.; Heinl, P.; Körner, C.; Singer, R.F. Nkenke, E.; Neukam, F.W.; Schlegel, K.A. In vivo performance of selective electrom beammelted Ti-6Al-4V structures. J. Biomed. Mater. Res. A 2009, in press, doi:10.1002/jbm.a.32337.

150. Li, J.P.; Habibovic, P.; van den Doel, M.; Wilson, C.E.; de Wijn, J.R.; van Blitterswijk, C.A.; de Groot, K. Bone ingrowth in porous titanium implants produced by 3D fiber deposition. Biomaterials 2007, 28, 2810-2820.

151. Bottino, M.C.; Coelho, P.G.; Henriques, V.A.R.; Higa, O.Z.; Bressiani, A.H.A.; Bressiani, J.C. Processing, characterization, and in vitro/in vivo evaluations of powder metallurgy processed Ti13Nb-13Zr alloys. J. Biomed. Mater. Res. A 2009, 88, 689-696.

152. Chang, Y.S.; Gu, H.O.; Kobayashi, M.; Oka, M. Influence of various surface treatments on histological fixation of titanium implants. J. Arthroplast. 1998, 13, 816-825.

153. Lopez-Heredia, M.A.; Goyenvalle, E.; Aguado, E.; Pilet, P.; Leroux, C.; Dorget, M.; Weiss, P.; Layrolle, P. Bone ingrowth in rapid prototyped porous titanium implants. J. Biomed. Mater. Res. A 2008, 85, 664-673. 
154. Takemoto, M.; Fujibayashi, S.; Neo, M.; So, K.; Akiyama, N.; Matsushita, T.; Kokubo, T.; Nakamura, T. A porous bioactive titanium implant for spinal interbody fusion: An experimental study using a canine model. J. Neurosurg. Spine 2007, 7, 435-443.

155. Pinto-Faria, P.E.; Carvalho, A.L.; Borges-Felipucci, D.N.; Wen, C.; Sennerby, L.; Salata, L.A. Bone formation following implantation of titanium sponge rods into humeral osteonomies in dogs: A histological and histomorphometrical study. Clin. Implants Dent. Rel. Res. 2008, in press, doi: 10.1111/j.1708-8208.2008.00132.x.

156. Walboomers, X.F.; Jansen, J.A. Bone tissue induction, using a COLLOSS $®$-filled titanium fiber mesh-scaffolding material. Biomaterials 2005, 26, 4779-4785.

157. van Jonbergen, H-P.W.; Spruit, M.; Anderson, P.G.; Pavlov, P.W. Anterior cervical interbody fusion with a titanium box cage: Early radiological assessment of fusion and subsidence. Spine $J$. 2005, 5, 645-649.

158. Eck, K.R.; Bridwell, K.H.; Ungacta, F.F.; Lapp, M.A.; Lenke, L.G.; Daniel, R.K. Analysis of titanium mesh cages in adults with minimum two-year follow-up. Spine J. 2000, 25, 2407-2415.

159. Kuttenberger, J.J.; Hardt, N. Long-term results following reconstruction of craniofacial defects with titanium micro-mesh systems. J. Cranio-Max.-Fac. Surg. 2001, 29, 75-81.

160. Bystedt, H.; Rasmusson, L. Porous titanium granules used as osteoconductive material for sinus floor augmentation: A clinical pilot study. Clin. Implant Dent. Relat. Res. 2009, 11, 101-105.

161. Jaquiéry, C.; Aeppli, C.; Cornelius, P.; Palmowsky, A.; Kunz, C.; Hammer, B. Reconstruction of orbital wall defects: critical review of 72 patients. Int. J. Oral Maxillofac. Surg. 2007, 36, 193-199.

162. Scholz, M.; Wehmöller, M.; Lehmbrock, J.; Schmieder, K.; Engelhardt, M.; Harders, A.; Eufinger, H. Reconstruction of the temporal contour for traumatic tissue loss using a CAD/CAM-prefabricated titanium implant-case report. J. Cranio-Max.-Fac. Surg. 2007, 35, 388-392.

163. Ayers, R.A.; Simske, S.J.; Bateman, T.A.; Petkus, A.; Sachdeva, R.L.C.; Gyunter, V.E. Effect of nitinol implant porosity on cranial bone ingrowth and apposition after 6 weeks. J. Biomed. Mater. Res. A 1999, 45, 42-47.

164. Kujala, S.; Ryhänen, J.; Danilov, A.; Tuukkanen, J. Effect of porosity on the osseointegration and bone ingrowth of a weight-bearing-nickel-titanium bone graft substitute. Biomaterials 2003, 24, 4691-4697.

165. Simske, S.J.; Sachdeva, R. Cranial bone apposition and ingrowth in a porous nickel-titanium implant. J. Biomed. Mater. Res. A 1995, 29, 527-533.

166. Shishkovsky, I.V.; Volova, L.T.; Kuznetsov, M.V.; Morozov, Y.G.; Parkin, I.P. Porous biocompatible implants and tissue scaffolds synthesized by selective laser sintering from $\mathrm{Ti}$ and NiTi. J. Mater. Chem. 2008, 18, 1309-1317.

167. Zhu, S.L.; Yang, X.J.; Chen, M.F.; Li, C.Y.; Cui, Z.D. Effect of porous NiTi alloy on bone formation: a comparative investigation with bulk NiTi alloy for 15 weeks in vivo. Mater. Sci. Eng. C 2008, 28, 1271-1275.

168. Rhalmi, S.; Odin, M.; Assad, M.; Tabrizian, M.; Rivard, C.H.; Yahia L.H. Hard, soft tissue and in vitro cell response to porous nickel-titanium: A biocompatibility evaluation. Biomed. Mater. Eng. 1999, 9, 151-162. 
169. Rhalmi, S.; Charette, S.; Assad, M.; Coillard, C.; Rivard, C.H. The spinal cord dura mater reaction to nitinol and alloy particles: A 1 year study in rats. Eur. Spine J. 2007, 16, 1063-1072.

170. Wu, S.; Liu, X.; Hu, T.; Chu, P.K.; Ho, J.P.Y.; Chan, Y.L.; Yeung, K.W.K.; Chu, C.L.; Hung, T.F.; Huo, K.F.; Chung, C.Y.; Lu, W.W.; Cheung, K.M.C.; Luk, K.D.K. A Biomimetic hierarchical scaffold: Natural growth of nanotitanates on three-dimensional microporous Tibased metals. Nano Lett. 2008, 8, 3803-3808.

171. Wang, Y.; Chai, W.; Wang, Z.-G.; Zhou, Y.-G.; Zhang, G.-Q.; Chen, J.-Y. Superelastic cage implantation. A new technique for treating osteoncrosis of the femoral head with middle-term follow-ups. J. Arthroplast. 2009, in press, doi: 10.1016/j.arth.2008.07.010.

172. Arsenova, I.A.; Sysolyatin, P.G.; Gunther, V.E. Midface endoprosthetics with superelastic porous NiTi implants. Int. J. Oral Maxillofac. Surg. 2005, 34 (Suppl 1), 20.

173. Zhang, E.; Zou, C. Porous titanium and silicon-substituted hydroxyapatite biomodification prepared by a biomimetic process: characterization and in vivo evaluation. Acta Biomater. 2009, in press, doi: 10.1016/j.actbio.2009.01.014.

174. Peng, L.; Bian, W.; Liang, F.; Xu, H. Implanting hydroxyapatite-coated porous titanium with bone morphogenetic protein-2 and hyaluronic acid into distal femoral metaphysic of rabbits. Chin. J. Traumatol. 2008, 11, 179-185.

175. Lopez-Heredia, M.A.; Sohier, J.; Gaillard, C.; Quillard, S. Rapid prototyping porous titanium coated with calcium phosphate as a scaffold for bone tissue engineering. Biomaterials 2008, 29, 2608-2615.

176. Sargeant, T.D.; Guler, M.O.; Oppenheimer, S.M.; Mata, A.; Satcher, R.L.; Dunand, D.C.; Stupp, S.I. Hybrid bone implants: Self-assembly of peptide amphiphile nanofibers within porous titanium. Biomaterials 2008, 29, 161-171.

177. Sikavitsas, V.I.; van den Dolder, J.; Bancroft, G.N.; Jansen, J.A.; Mikos, A.G. Influence of the un vitro culture period on the in vivo performance of cell/titanium bone tissue-engineered constructs using a rat cranial critical size defect model. J. Biomed. Mater. Res. A 2003, 67, 944-951.

178. Vehof, J.W.M.; Spauwen, P.H.M.; Jansen, J.A. Bone formation in calcium-phosphate-coated titanium mesh. Biomaterials 2000, 21, 2003-2009.

179. Habibovich, P.; Li, J.; van der Valk, C.M.; Meijer, G.; Layrolle, P.; van Blitterswijk, C.A.; de Groot, K. Biological performance of uncoated and octacalcium phosphate-coated Ti6Al4V. Biomaterials 2005, 26, 23-36.

180. Hartman, E.H.M.; Vehof, J.W.M.; Spauwen, P.H.M.; Jansen, J.A. Ectopic bone formation in rats: the importance of the carrier. Biomaterials 2005, 26, 1829-1835.

181. Kroese-Deutman, H.C.; van den Dolder, J.; Spauwen, P.H.M.; Jansen, J.A. Influence of RGDloaded titanium implants on bone formation. Tissue Eng. 2005, 11, 1867-1875.

182. van den Dolder, J.; Farber, E.; Spauwen, P.H.M.; Jansen, J.A. Bone reconstruction using titanium fiber mesh combined with rat bone marrow stromal cells. Biomaterials 2003, 24, 1745-1750.

183. Vehof, J.W.M.; Haus, M.T.U.; Ruijter, A.E.; Spauwen, P.H.M.; Jansen, J.A. Bone formation in transforming growth factor beta-I-loaded tiatanium fiber mesh implants. Clin. Oral Impl. Res. 2002, 13, 94-102. 
184. Kroese-Deutman, H.C.; Vehof, J.W.M.; Spauwen, P.H.M.; Stoelinga, P.J.W.; Jansen, J.A. Orthotopic bone formation in titanium fiber mesh loaded with platelet-rich plasma and placed in segmental defects. Int. J. Oral Maxillofac. Surg. 2008, 37, 542-549.

185. Sargeant, T.D.; Oppenheimer, S.M.; Dunand, D.C.; Stupp, S.I. Titanium foam-bioactive nanofiber hybrids for bone regeneration. J. Tissue Eng. Regen. Med. 2008, 2, 455-462.

186. Chen, F.; Feng, X.; Wu, W.; Ouyang, H.; Gao, Z.; Cheng, X.; Hou, R.; Mao, T. Segmental bone tissue engineering by seeding osteoblasts precursor cells into titanium mesh-coral composite scaffolds. Int. J. Oral Maxillofac. Surg. 2007, 36, 822-827.

187. Gordon, W.J.; Conzemius, M.G.; Birdsall, E.; Wannemuehler, Y.; Mallapragada, S.; Lewallen, D.G.; Yaszemski, M.J.; O'driscoll-S., W. D. Chrondroconductive potential of tantalum trabecular metal. J. Biomed. Mater. Res. B 2005, 75, 229-233.

188. Bobyn, J.D.; Hacking, S.A.; Krygier, J.J.; Harvey, E.J.; Little ,D.G.; Tanzer, M. Zoledronic acid causes enhancement of bone growth in porous implants. J. Bone Joint Surg. Br. 2005, 87B, 416-420.

189. Barrère, F.; van der Valk, C.M.; Dalmeijer, R.A.J.; Meijer, G.; van Blitterswijk, C.A.; de Groot, K.; Layrolle, P. Osteogenicity of octacalcium phosphate coatings applied on porous metal implants. J. Biomed. Mater. Res. A 2003, 66, 779-788.

190. Barrère, F.; van der Valk, C.M.; Dalmeijer, R.A.J.; de Groot, K.; Layrolle, 'P. Osteointegration of Biomimetic apatite coating applied onto dense and porous metal implants in femurs of goats. $J$. Biomed. Mater. Res. B 2003, 67, 655-665.

191. Lima, E.G.; Chao, P.G.; Ateshian, G.A.; Bal, B.S.; Cook, J.L.; Vunjak-Novakovic, G.; Hung, C.T. The effect of devitalized trabecular bone on the formation of osteochondral tissueengineered constructs. Biomaterials 2008, 29, 4292-4299.

192. Reinholz, G.G.; Fitzsimmons, J.S.; Zobitz, M.E.; An, K.-N.; Lewallen, D.G.; Yaszemski, M.J.; O’Driscoll, S.W. Development of a biologic prosthetic composite for cartilage repair. Tissue Eng. 2005, 11, 1368-1378.

193. Zou, X.; Li, H.; Zou, L.; Mygind, T.; Lind, M.; Bünger C. Porous tantalum trabecular metal scaffolds in combination with a novel marrow processing technique to replace autograft. Adv. Exp. Med. Biol. 2007, 585, 197-208.

194. Sidhu, K.S.; Prochnow, T.D.; Schmitt, P.; Fischgrund, J.; Weisbrode, S.; Herkowitz, H.N. Anterior cervical interbody fusion with rhBMP-2 and tantalum in a goat model. Spine J. 2001, 1, 331-340.

195. Li, H.; Zou, X.; Woo, C.; Ding, M.; Lind, M.; Bünger, C. Lumbar spine fusion with a novel tantalum-coated carbon fibre cage loaded with Colloss ${ }^{\circledR}$. Eur. Cell. Mater. 2005, 10 (Suppl 3), 64.

196. Thalgott, J.S.; Giuffre, J.M.; Klezl, Z.; Timlin, M. Anterior lumbar interbody fusion with titanium mesh cages, coralline hydroxyapatite, and demineralized bone matrix as part of a circumferential fusion. Spine J. 2002, 2, 63-69.

197. Thalgott, J.S.; Xiongsheng, C.; Giuffre, J.M. Single stage anterior cervical reconstruction with titanium mesh cages, local bone graft, and anterior plating. Spine J. 2003, 3, 294-300. 
198. Thongtrangan, I.; Balabhadra, R.S.V.; Le, H.; Park, J.; Kim, D.H. Vertebral body replacement with an expandable cage for reconstruction after spinal tumor resection. Neurosurg. Focus 2003, $8,1-6$.

199. Niu, C.C.; Chen, L.H.; Lai, P.L.; Fu, T.S.; Chen, W.J. Trapezoidal titanium cage in anterior cervical interbody fusion: A clinical experience. Chang Gung Med. J. 2005, 28, 212-221.

200. Chuang, H.C.; Cho, D.Y.; Chang, C.S.; Lee, W.Y.; Jung-Chung, C.; Lee, H.C.; Chen, C.C. Efficacy and safety of the use of titanium mesh cages and anterior cervical plates for interbody fusion after anterior cervical corpectomy. Surg. Neurol. 2006, 65, 464-471.

201. Boden, S.D.; Zdeblick, T.A.; Sandhu, H.S.; Heim, S.E. The use of rhBMP-2 in interbody fusion cages. Definitive evidence of osteoinduction in humans: a preliminary report. Spine J. 2000, 25, 376-381.

202. Regnér, L.; Carlsson, L.; Kärrholm, J.; Herberts, P. Ceramic coating improves tibial component fixation in total knee arthroplasty. J. Arthroplast. 1998, 13, 882-889.

203. Hibi, H.; Yamada, Y.; Ueda, M.; Endo, Y. Alveolar cleft osteoplasty using tissue-engineered osteogenic material. Int. J. Oral. Maxillofac. Surg. 2006, 35, 551-555.

(C) 2009 by the authors; licensee Molecular Diversity Preservation International, Basel, Switzerland. This article is an open-access article distributed under the terms and conditions of the Creative Commons Attribution license (http://creativecommons.org/licenses/by/3.0/). 